\title{
ACÚMULO DE NITRATO, ABSORÇÃO DE NUTRIENTES E PRODUÇÃO DE DUAS CULTIVARES DE ALFACE CULTIVADAS EM HIDROPONIA, EM FUNÇÃO DE DOSES CONJUNTAS DE NITROGÊNIO E POTÁSSIO
}

JONAS RUSCHEL

Engenheiro Agrônomo

Orientador: Prof. Dr. QUIRINO AUGUSTO DE CAMARGO CARMELLO

Dissertaçāo apresentada à Escola Superior de Agricultura "Luiz de Queiroz", Universidade de São Paulo, para obtençāo do título de Mestre em Agronomia, Área de Concentração: Solos e Nutriçāo de Plantas.

P I R A C I C A B A

Estado de São Paulo - Brasil

Dezembro - 1998 
Dados Internacionais de Catalogação na Publicação (CIP)

DIVISÃO DE BIBLIOTECA E DOCUMENTAÇÃO - Campus “Luiz de Queiroz"/USP

Ruschel, Jonas

Acúmulo de nitrato, absorção de nutrientes e produção de duas cultivares de alface cultivadas em hidroponia, em função de doses conjuntas de nitrogênio e potássio / Jonas Ruschel. - - Piracicaba, 1998.

76p. : il.

Dissertação (mestrado) - - Escola Superior de Agricultura Luiz de Queiroz, 1998. Bibliografia.

1.Alface 2. Hidroponia 3. Nitrato 4. Nitrogênio 5. Potássio 6. Solução nutritiva I. Titulo

CDD 635.52 
Ao Criador por me guiar e acompanhar em tudo que faço, Agradeço.

Aos meus pais, Pedro e Elvira, aos meus irmãos, Jaime e Genésio, pelo carinho, confiança e incentivo,

Ofereço.

Para a minha querida e amada noiva Luciana Kolm, pelo carinho, compreensão e pelo constante incentivo para perseguir meus sonhos, Dedico. 


\section{AGRADECIMENTOS}

Ao Prof. Dr. Quirino Augusto de Camargo Carmello pela amizade, orientação e apoio, que contribuíram para a realização deste trabalho.

Ao Setor de Nutrição Mineral de Plantas do Departamento de Química da Escola Superior de Agricultura "Luiz de Queiroz"/USP pela infra-estrutura e pelo apoio durante a realização deste trabalho.

Aos Professores Dr. Antonio Roque Dechen e Dr. Francisco Antonio Monteiro pela amizade e constante incentivo.

À Coordenação de Aperfeiçoamento de Pessoal de Nivel Superior (CAPES) pelo apoio financeiro através da Bolsa concedida.

À Comissão de Apoio à Vila Estudantil (CAVE) pela moradia concedida.

Aos funcionários do Setor de Nutrição Mineral de Plantas da ESALQ/USP: Alexandre de Oliveira, Edinéia Cristina S. Mondoni, Lurdes A. Dário de González, Lúcia Helena S. Pavan Forti, Nivanda Maria de Moura, Mirtes Ventura Sesso e Sueli Maria Amaral Campos Bovi, pela amizade e pelo auxilio prestado na condução do estudo e na realização das análises químicas.

À Bibliotecária Kátia M. Andrade Ferraz pela correção das referência bibliográficas.

Ao Prof. Dr. Raymond Stanley Pacovsky pela auxílio na confecção e correção do "summary".

Ao Prof. Dr. Decio Barbin e a Profa. Dra. Maria Cristina Stolf Nogueira pela ajuda na elaboração do planejamento experimental e análises estatísticas, respectivamente.

Aos colegas Alberto Carlos de Campos Bernardi, Antônio Sampaio Baptista, Carla Rossi, César de Castro, Fábio Alvares de Oliveira, Glaucia Regina Anti e João Batista Rodrigues de Abreu pela amizade e pelo grande auxílio prestado na fase inicial do trabalho. 
Aos colegas da sala de Pós-graduação do Setor de Nutrição Mineral de Plantas da ESALQ/USP pela amizade, pelas sugestões no estudo e pelas experiências de vida transmitidas.

A todas as pessoas que não foram mencionadas mas que auxiliaram de alguma forma para que este trabalho pudesse ser realizado com êxito. 


\section{SUMÁRIO}

Página

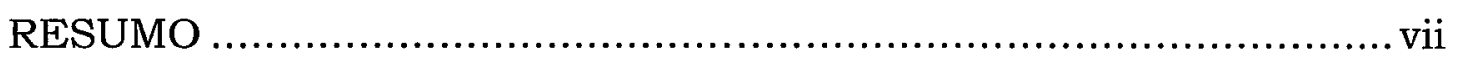

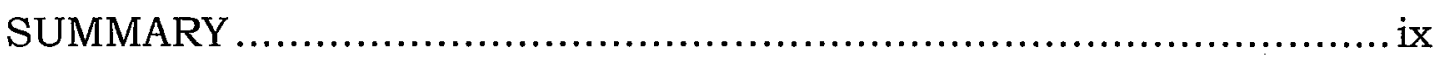

1 INTRODUÇÃO .............................................................. 1

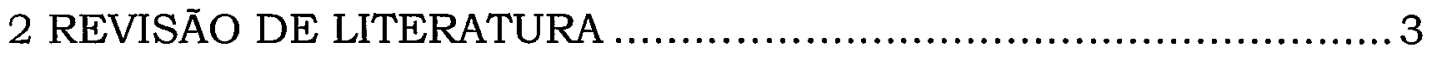

2.1 O gênero Lactuca .......................................................... 3

2.2 Nitrogênio .................................................................. 4

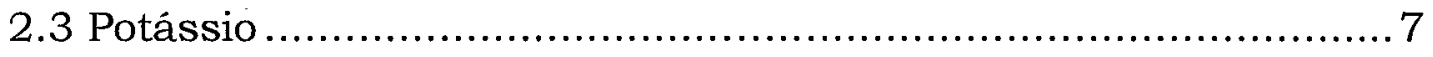

2.4 Alface em fluxo laminar de solução (NFT) …........................ 9

2.4.1 Necessidades nutricionais ........................................... 9

2.4.2 Assimilação e redução do nitrato...................................... 11

3 MATERIAL E MÉTODOS ................................................. 14

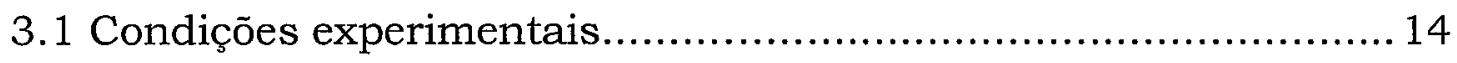

3.2 Delineamento experimental, tratamentos e condução do

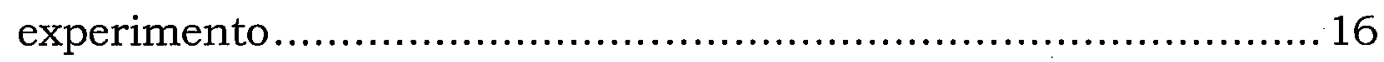

3.3 Amostragens e determinações ......................................... 18

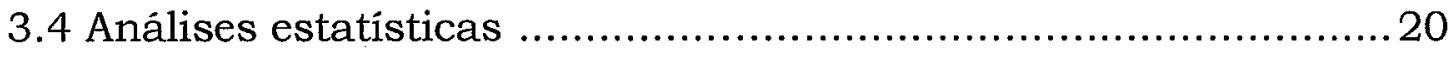

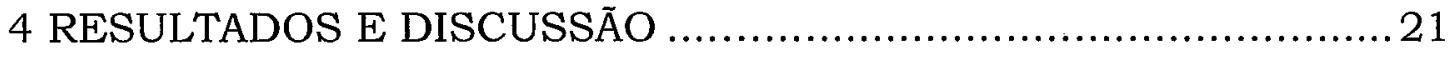

4.1 Consumo de solução nutritiva................................................ 21

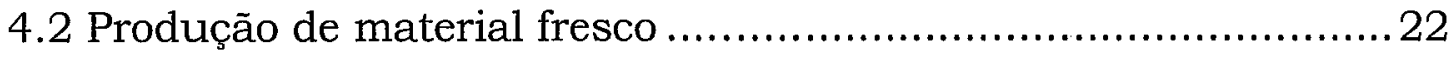

4.3 Produção de material seco ............................................ 27

4.4 Concentração de nitrato na parte aérea................................... 33

4.5 Concentração e absorção de nutrientes .................................. 36

4.5.1 Nitrogênio ................................................................ 36

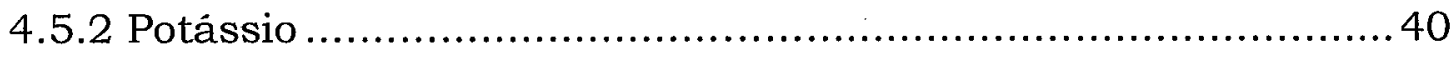

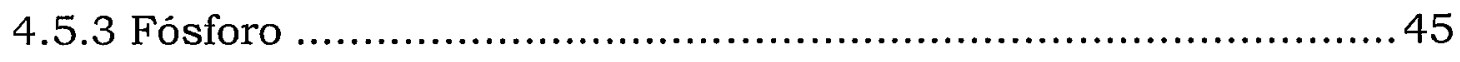

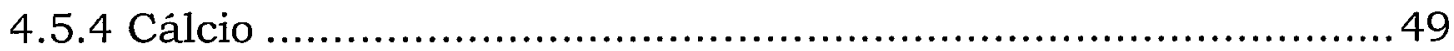

4.5.5 Magnésio .................................................................. 54

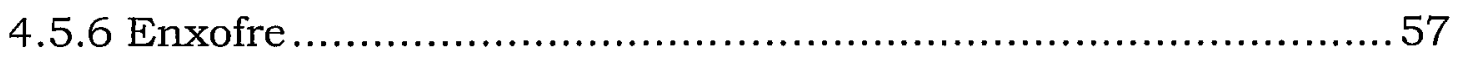




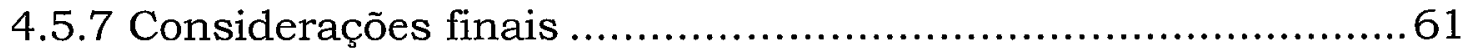

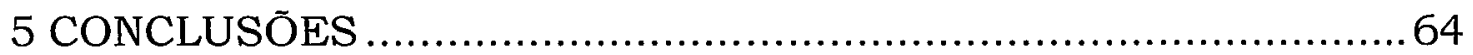

REFERÊNCIAS BIBLIOGRÁFICAS ........................................ 66

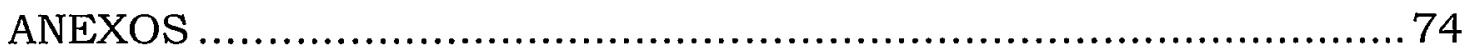




\section{ACÚMULO DE NITRATO, ABSORÇÃO DE NUTRIENTES E PRODUÇÃO DE DUAS CULTIVARES DE ALFACE CULTIVADAS EM HIDROPONIA, EM FUNÇÃO DE DOSES CONJUNTAS DE NITROGÊNIO E POTÂSSIO}

Autor: Jonas Ruschel

Orientador: Prof. Dr. Quirino A. de C. Carmello

\section{RESUMO}

No Brasil é crescente a utilização de cultivos hidropônicos de alface, sem contudo haver informações mais precisas quanto ao uso de fontes de nutrientes, mais especificamente sobre o efeito da utilização do nitrato de potássio como, fonte de nitrogênio e potássio, sobre o acúmulo de nitrato. O limite máximo de nitrato estabelecido por alguns países da Europa é de $4.000 \mathrm{mg} \mathrm{kg}^{-1}$ no material fresco em folhas de alface cultivadas sob hidroponia, mostrando a grande preocupação com a toxicidade e o acúmulo de nitrato pelo organismo humano, em função da grande utilização de adubos nitrogenados. O fornecimento de $\mathrm{N}$ em excesso para a planta causa acúmulo de nitrato nos tecidos vegetais.

O objetivo do experimento foi avaliar o comportamento de duas cultivares de alface (Lactuca sativa L.), cultivadas com a técnica do fluxo laminar de solução (NFT ${ }^{1}$ ) e submetidas a 4 doses de $\mathrm{N}$ e K na solução nutritiva. Todos os nutrientes foram mantidos constantes, exceto o $\mathrm{N}$, que acompanhou o $\mathrm{K}$, em função da utilização de $\mathrm{KNO}_{3}$ comercial. Os tratamentos, com as doses de $\mathrm{N}$ e de $\mathrm{K}$ em $\mathrm{mg} \mathrm{L}^{-1}$ foram os seguintes: 220 e 160; 240 e 220; 260 e 280 e 280 e 340, respectivamente.

\footnotetext{
${ }^{1}$ Nutrient Film Technique
} 
O delineamento experimental utilizado foi o inteiramente casualizado, com duas cultivares (Vera e Marisa) e quatro doses fixas de $\mathrm{N}$ e K, com três repetiçōes por tratamento, num total de 24 canais.

As cinco plantas centrais de cada parcela foram coletadas no final do ciclo (17 dias após o transplante), separadas em parte aérea e sistema radicular. Os parâmetros avaliados foram: o consumo de solução nutritiva, o rendimento de material fresco e seco da parte aérea e da planta inteira, a concentração de nitrato na parte aérea, teor e quantidade dos nutrientes absorvidos pela parte aérea e pela planta inteira.

Os resultados permitiram concluir que não houve aumentos significativos na quantidade de nitrato na parte aérea em função dos tratamentos.

As produções de material seco e de material fresco da parte aérea e da planta inteira das plantas de alface foram influenciadas pelos tratamentos, ajustando-se a um modelo linear para a cultivar Marisa e quadrático para a cultivar Vera.

As concentrações de $\mathrm{K}$ e de Ca na parte aérea e na planta inteira e de enxofre na parte aérea, tiveram aumentos significativos em função das doses na solução nutritiva, com interação entre doses e cultivares. $\mathrm{O} \mathrm{Mg}$ teve decréscimos significativos, com interação apenas para doses.

As quantidades de $\mathrm{N}, \mathrm{P}, \mathrm{K}$, Ca e $\mathrm{S}$ absorvidos pela parte aérea $\mathrm{e}$ pela planta inteira, tiveram aumentos significativos em função das doses de $\mathrm{N}$ e de $\mathrm{K}$ na solução nutritiva, com interação entre doses e cultivares.

A cultivar Vera teve uma melhor eficiência na utilização de $\mathrm{N}$ e de $\mathrm{K}$, possibilitando uma economia de fertilizantes na solução nutritiva. 


\title{
NITRATE ACCUMULATION, NUTRIENT ABSORPTION AND PRODUCTION IN TWO VARIETIES OF HYDROPONIC ALLY GROWN LETTUCE: NITROGEN AND POTASSIUM EFFECTS
}

\author{
Author: Jonas Ruschel \\ Adviser: Prof. Dr. Quirino A. de C. Carmello
}

\section{SUMMARY}

The use of hydroponics for lettuce cultivation is a practice which is increasing in Brazil. However, there is a need for more precise information related to the use of nutrient sources, mainly with regard to potassium and nitrate fertilizers, and in addtition, with nitrate accumulation. The excessive use of nitrogen fertilization is likely to increase problems due to nitrate accumulation. The maximum for nitrate concentration in plant tissue in some European countries is $4,000 \mathrm{mg} \mathrm{kg}^{-1}$. Our hypothesis is that when $\mathrm{N}$ is abundant, nitrate accumulates in the plant.

The objective of this experiment was to evaluate the behavior of two cultivars of lettuce grown using a Nutrient Film Technique (NFT) with 4 combinations of $\mathrm{K}$ and $\mathrm{N}$ doses in the nutrient solution. All the nutrient concentrations were maintained constant, except for $\mathrm{N}$, which accompanied $\mathrm{K}$ since we used a common commercial $\mathrm{KNO}_{3}$ source. Nitrogen and $\mathrm{K}$ were applied as (mg L $\mathrm{L}^{-1}$ ): 220 and 160; 240 and 220; 260 and 280; and 280 and 340, respectively.

The experimental design was randomized with 2 lettuce cultivars (Vera and Marisa) and 4 rates of $\mathrm{N}$ and $\mathrm{K}$, with 3 replicates per treatement for a total of 24 flats. Plants were grown in greenhouse in 
large flats for 17 days. The five central plants of each flat were collected at harvest. Roots and shoots were separated. The following parameters were evaluated: consumption of solution, production of shoot and root fresh and dry weights, total shoot nitrate and the concentration and accumulation of macronutrients absorbed by shoots.

The results indicated that there was no significant increase in the amount of shoot nitrate. Dry and fresh weight for lettuce shoots and roots were influenced by the fertilizer addition. Growth increased linearly with $\mathrm{N}$ and $\mathrm{K}$ addition (cv. Marisa) or in a quadratic fashion (cv. Vera).

The $\mathrm{K}$ and Ca concentrations, in roots and in shoots increased as a function of $\mathrm{N}$ and $\mathrm{K}$ additions in the nutrient solution, with an interaction between rates and cultivares. Magnesium decreased significantly with $\mathrm{N}$ and $\mathrm{K}$ additions, with interactions only with increasing levels of fertilizer.

The accumulation of $\mathrm{N}, \mathrm{P}, \mathrm{K}, \mathrm{Ca}$ and $\mathrm{S}$ in both shoots and roots significantly increased as a function of $\mathrm{N}$ and $\mathrm{K}$ dose, with interactions between rates and cultivars.

The cv. Vera had the best efficiency with regards to $\mathrm{N}$ and $\mathrm{K}$ utilization, permitting the economy of those fertilizers in the nutrient solution. 


\section{INTRODUÇĀO}

A alface (Lactuca sativa L.) é a hortaliça mais consumida e considerada de grande importância na alimentação do brasileiro, o que assegura a essa cultura importância econômica expressiva. $\mathrm{O}$ aumento do consumo de hortaliças folhosas, entre elas a alface, nas grandes regiões de consumo torna necessário a diminuição ou o encurtamento do ciclo das culturas para um ganho no número de ciclos por ano.

A alface é cultivada tradicionalmente no solo, nos cinturões verdes das grandes cidades, exigindo-se os cuidados e tratos culturais necessários a todas as culturas. Atualmente, está sendo utilizada uma técnica moderna de cultivo comercial de alface, denominada hidroponia (hidro = água; ponos = trabalho), a qual permite o cultivo dessa hortaliça o ano todo, obtendo-se produtividades mais elevadas, produtos com qualidade melhor e preços de mercado maiores.

Doses cada vez maiores de fertilizantes nitrogenados vêm sendo utilizadas para aumentar a produção e para contribuir para a diminuição do ciclo da cultura, porém podem ocorrer problemas devido ao acúmulo de nitrato no tecido vegetal.

Esse acúmulo de nitrato pode ser prejudicial para a saúde humana, quando seus teores no tecido forem acima dos considerados como toleráveis. Esse fato gera uma preocupação muito grande com a toxicidade e o acúmulo de nitrato pelo organismo humano, em função da grande utilização de adubos nitrogenados, como os nitratos em hortaliças para consumo "in natura". O consumo a longo prazo de 
plantas comestiveis cultivadas com excesso de uso de fertilização nitrogenada poderia causar efeitos negativos em humanos, devido à ingestão total de nitratos e nitritos em doses elevadas.

Os limites dos niveis tolerados para nitrato e nitrito em países europeus são muito diferentes dos paises americanos, pois, o consumo diário e as condições edafoclimáticas são diferentes das encontradas em nossa região.

O aumento da concentração de nitrato no meio de cultivo, solo ou solução nutritiva, causa aumentos nas concentração de nitrato nos tecidos vegetais. Em nossas condições de produção é necessário obter-se essa informação. 


\section{REVISÃo DE LITERATURA}

\subsection{0 gênero Lactuca}

O gênero Lactuca tem seu principal centro de origem na região do Mar Mediterrâneo, onde as primeiras indicações de sua existência datam de 4.500 anos A.C., em pinturas nos túmulos dos Faraós do Egito. Caracteriza-se por ser uma planta típica de autofecundação. Existem três teorias que tentam explicar a origem da diversidade de formas da alface cultivada. A primeira teoria considera como origem para a alface as raças selvagens de Lactuca sativa L.. A segunda considera-a como originada diretamente da Lactuca serriola L.. A terceira propõe que a alface cultivada tenha se originado da hibridação entre espécies selvagens de alface (Lindqvist, 1960).

Conti (1994) citou que a alface se disseminou pela Europa junto com a expansão do Império Romano e, o seu cultivo prosperou em ambientes frios, pois pode tolerar temperaturas baixas.

O cultivo da alface em casa-de-vegetação (estufa) tem-se mostrado uma alternativa técnica econômica interessante para as regiões com invernos rigorosos ou verões chuvosos. Além de proteger a cultura de fatores adversos tais como: geadas, excesso de chuva, granizo e vento, as modificações micrometeorológicas no interior da casa-devegetação permitem ganhos na produtividade, na qualidade dos 
produtos e na precocidade da produção (Santos \& Souza, 1996; Furlani, 1997).

Santos \& Souza (1996), em estudo comparativo do cultivo da cultivar Regina de alface em casa-de-vegetação e em ambiente natural, constataram que as condições de casa-de-vegetação proporcionaram uma formação de maior área foliar e antecipação da colheita em 17 dias, enquanto que as condições do ambiente natural favoreceram a formação de maior número de folhas e maior acúmulo de material seco da planta. As plantas cultivadas em ambiente protegido, devido às modificações micrometeorológicas condicionadas pela casa-de-vegetação, apresentaram mais água em seus tecidos, produzindo folhas menos fibrosas e mais palatáveis.

\subsection{Nitrogênio}

O nitrogênio desempenha na planta, funções fisiológicas, estruturais e de osmorregulação. Segundo Mengel \& Kirkby (1987), Marschner (1995) e Hopkins (1995) o nitrogênio é absorvido pelas raizes das plantas na forma iônica, como ions nitrato $\left(\mathrm{NO}_{3}{ }^{-}\right)$e/ou amônio $\left(\mathrm{NH}_{4}{ }^{+}\right)$. A maior parte do amônio é reduzido e incorporado em compostos orgânicos nas raízes. Por outro lado, o nitrato é móvel no xilema, podendo ser armazenado nos vacúolos das células das raízes e principalmente na parte aérea. $O$ nitrato acumulado no vacúolo das células, é importante no balanço de cátions e de ânions, na regulação osmótica e no equilíbrio eletroquímico celular (Marschner, 1995).

Após a absorção, o nitrato pode ser reduzido nas raizes ou translocado à parte aérea. O nitrato é reduzido até amônio pelas atividades das enzimas redutase do nitrato e redutase do nitrito, em 
reações localizadas no citoplasma e no cloroplasto, respectivamente (Redinbaugh \& Campbell, 1991). O amônio é incorporado em cetoácidos formando aminoácidos, os quais seguem rotas metabólicas diferentes, como a sintese de proteínas, coenzimas e ácidos nucléicos, entre outras moléculas vitais (Marschner, 1995). O teor de nitrato nos tecidos vegetais é determinado por vários fatores, com destaque para: luminosidade, disponibilidade de nitrato e molibdênio, interação de nutrientes, tipos e fontes de adubos nitrogenados e inibidores de nitrificação (Scharpf, 1991).

A luz atua na redução do nitrato e do nitrito por meio da indução da enzima redutase do nitrato e pelo aumento da disponibilidade de NADH que é, o doador de elétrons na reação (Marschner, 1995). A luz também determina o acúmulo de nitrato em plantas, porque os açúcares sintetizados em uma maior atividade fotossintética, substituem o nitrato como componente osmótico (Behr \& Wiebe, 1992).

O nitrato é acumulado em maior concentração nos vacúolos das células quando as plantas são submetidas a baixa intensidade luminosa, pois nessa condição, a sintese de osmorreguladores orgânicos importantes, como o malato, é reduzida (Blom-Zandstra \& Lampe, 1985). Segundo Maynard \& Barker (1972), os órgãos em ordem decrescente de acúmulo de nitrato são: caule, pecíolo, folhas, raizes e partes reprodutivas.

O teor de nitrato nas plantas é influenciado pela disponibilidade de molibdênio, que é um dos componentes do sistema de transferência de elétrons da enzima redutase do nitrato (Gupta \& Lipset, 1981; Marschner, 1995). A deficiência metabólica de molibdênio resulta em um acúmulo de nitrato e pode promover, também, alterações morfológicas nas plantas. Barros (1979) verificou que alfaces apresentavam cabeças abertas e crescimento retardado, em função da deficiência de molibdênio. 
O consumo de vegetais ou de água contendo altos teores de nitrato representa um risco à saúde de consumidores, pois pode favorecer casos de cianose ou metahemoglobinemia e até de câncer, pela formação de nitrosaminas (Wright \& Davison, 1964).

Em adultos com saúde estável, nenhuma redução de nitrato a nitrito ocorre no estômago, pois a acidez local inibe a ação de bactérias. Porém, as crianças e os adultos com distúrbios gástricos, que apresentam maior $\mathrm{pH}$ estomacal, são mais susceptivel às desordens de saúde associadas à ingestão de nitrato, que é seguido da redução para nitrito (Reinink, 1993). O nitrito na circulação sanguínea atua na oxigenação do íon ferroso da molécula de hemoglobina, transformando-o em metahemoglobina, uma forma isomérica incapaz de transportar oxigênio às células (Wright \& Davison, 1964). A metahemoglobinemia é verificada quando $100 \mathrm{~g} \mathrm{~kg}^{-1}$ da hemoglobina encontra-se na forma de metahemoglobina (Reinink, 1993).

As nitrosaminas, resultantes da reação de nitrito com aminas, são agentes cancerigenos no intestino (Croll \& Hayes, 1988). Segundo Reinink (1993), as nitrosaminas são sintetizadas favoravelmente sob condição de acidez estomacal maior, pois nessa condição a síntese de precursores, como $\mathrm{N}$-nitrosil (N-NO), é favorecida.

Os distúrbios de saúde humana associados ao nitrato fizeram com que vários países europeus estabelecessem teores máximos de nitrato em produtos consumido "in natura" e em água de consumo. A Holanda, em 1990, limitou o teor de nitrato em $4.000 \mathrm{mg} \mathrm{kg}^{-1}$ no material fresco de alface colhida em casa-de-vegetação (Richardson \& Hardgrave, 1992). Em 1995, o limite tolerável de nitrato foi reduzido para $3.500 \mathrm{mg} \mathrm{kg}{ }^{-1}$. Na água de consumo, Croll \& Hayes (1988) recomendaram teores de nitrato inferiores a $50 \mathrm{mg} \mathrm{L}^{-1}$. 


\subsection{Potássio}

A absorção de potássio é feita na forma iônica $\mathrm{K}^{+}$, sendo o processo essencialmente ativo (Marschner, 1995). As funções do potássio na planta são: ativador enzimático; regulador da turgidez do tecido; controlador da abertura e do fechamento dos estômatos, possibilitando o controle da concentração de $\mathrm{CO}_{2}$ na câmara subestomática a qual afeta diretamente a atividade fotossintética (Hopkins, 1995) e a transpiração. As plantas bem supridas de potássio utilizam melhor a água, necessitando uma menor quantidade de água para produzir determinada quantidade de material seco. O potássio atua no transporte de carboidratos (Mengel \& Kirkby, 1987); diminui os danos causados pelas geadas, pela seca e pela salinidade (Jones Jr., 1983; Douglas, 1985). A presença de potássio aumenta a resistência ao acamamento e a resistência às doenças, pois acelera o processo de lignificação das células esclerenquimáticas aumentando a espessura das paredes celulares do colmo (Marschner, 1995). Tem participação na qualidade dos produtos, aumentando a resistência ao transporte, manuseio e armazenamento, melhorando a cor, o tamanho, a acidez, o valor nutritivo e a qualidade industrial (Risse et al.,1989).

A disponibilidade de potássio para as plantas tem um papel importante no crescimento de seus órgãos, principalmente as folhas, devido às funções do potássio no que se refere ao metabolismo celular. Folhas de plantas com deficiência de potássio, geralmente tem taxas de fixação de carbono e translocação de assimilados reduzidas. A diminuição das taxas de troca de $\mathrm{CO}_{2}$ estão associadas diretamente ao fechamento dos estômatos (Huber, 1984). A abertura estomática e, conseqüentemente, a transpiração dependem de vários fatores, entre os quais a disponibilidade de potássio nos tecidos vegetais (Hopkins, 1995). 
O potássio é o cátion dominante nas plantas. Ele é transportado durante o fechamento e abertura estomatal. Para o fechamento do estômato, deve haver maiores concentrações fora das células guarda, ou seja, nas células adjacentes. Para a abertura do estômato, ele é acumulado nas células guarda, diminuindo o potencial hídrico da célula e, com isto, aumentando a sua turgescência. Esse aumento de turgescência vai proporcionar um aumento na abertura do estômato e uma menor resistência estomática (Hopkins, 1995).

O potássio tem uma influência forte nas relações água-planta, observando-se uma redução da taxa transpiratória sob condições de estresse nutricional de potássio. Este efeito pode ser bem visualizado através do aumento da resistência estomática em plantas submetidas a estresse de potássio. A resistência estomática é muito maior em plantas submetidas a estresse nutricional de potássio do que em plantas em condições normais de nutrição potássica. (Huber, 1984; Koksal et al., 1988).

O estresse nutricional de potássio afeta diretamente a fotossintese, diminuindo-a, porque interfere nos processos associados com o metabolismo da fixação fotossintética de carbono, provocando uma taxa de transpiração menor, através do aumento da resistência estomática e da diminuição da atividade de enzimas específicas, como a Sintetase do Fosfato de Sacarose (SPS) e da Rubisco (Ribulose difosfato Carboxilase). Com isso, a principal perda direta está na diminuição da produção. (Ozbun et al., 1965; Huber, 1984).

Em plantas submetidas ao estresse nutricional de potássio, observa-se um aumento na concentração de açúcares solúveis (hexoses) nas folhas. Isso é atribuído a uma diminuição na atividade das enzimas dependentes de $\mathrm{K}^{+}$, como é o caso da kinase do piruvato e a uma menor hidrólise de sacarose nos tecidos deficientes em potássio (Huber, 1984). 
Os principais produtos finais da fotossintese, formados e acumulados nas folhas são a sacarose e o amido, que servem como reservas energéticas para as mais diversas reações que ocorrem durante a fotossintese e/ou para seu consumo durante o periodo noturno (Hopkins, 1995). A deficiência de potássio causa uma diminuição dos seus teores foliares. A diminuição no acúmulo de amido nas folhas está relacionado com o aumento da atividade de enzimas específicas, como é o caso da amilase. A atividade dessa enzima, na ausência de potássio, aumentou mais de cinco vezes, quando comparado com uma planta bem nutrida em potássio. O desbalanço enzimático causado pela falta de potássio, promove a inibição de algumas enzimas, mas por outro lado induz a enzima amilase a degradar mais amido, causando uma diminuição do teor de amido armazenado nas folhas (Lavon, 1995).

\subsection{Alface em fluxo laminar de solução (NFT)}

\subsubsection{Necessidades nutricionais}

A extração de nutrientes pela alface varia conforme a época do ano, ficando em mg por planta por dia entre: 8,00-16,00 de N; 2,50-5,00 de $\mathrm{P}$ e 11,50-23,00 de $\mathrm{K}$ por planta e por dia e, durante o ciclo completo, em g por planta de 0,45 de N; 0,15 de P e 0,65 de K (Shippers, 1980).

Faquin et al. (1996) obtiveram as quantidades de nutrientes extraídas pela cultivar Verônica durante o ciclo comercial: 796, 142, 951, 325, 96 e 60 g/ 1000 plantas para N, P, K, Ca, Mg e S respectivamente. Pode-se observar que a extração total de nutrientes obedeceu a seguinte ordem decrescente: $\mathrm{K}>\mathrm{N}>\mathrm{Ca}>\mathrm{P}>\mathrm{Mg}>\mathrm{S}$. 
Conforme Jones Jr. (1983), o potássio tem concentrações entre 12,5 e $25,0 \mathrm{~g} \mathrm{~kg}^{-1}$ do material seco. Entretanto, Reuter \& Robinson (1997) consideraram que valores entre 56,0 e 92,0 $\mathrm{g} \mathrm{kg}^{-1}$ são adequados para o crescimento de alface e que a faixa indicada pelo primeiro autor é a zona de deficiência para potássio. Essas discrepâncias demonstram a necessidade de se conhecer a melhor faixa de concentração, bem como as possiveis diferenças entre as variedades e as épocas de cultivo.

De forma semelhante ao nitrogênio e ao fósforo, a concentração de potássio nas plantas é maior nos estágios iniciais, diminuindo com a idade (Faquin et al., 1996).

O aumento possivel nos teores de potássio nos tecidos, pela elevação da sua disponibilidade no meio, pode resultar em um desbalanço iônico entre os nutrientes $\mathrm{K}, \mathrm{Ca}$ e $\mathrm{Mg}$, ocasionando um estresse na planta. Quando o teor de potássio é maior do que de cálcio e o de magnésio, o primeiro sintoma de deficiência que provavelmente ocorre seja o do magnésio, podendo também induzir à deficiência de cálcio. O desbalanceamento entre esses três cátions ocorre devido aos excessos na fertilização com $\mathrm{K}$, sendo que este é absorvido e transportado na planta mais rapidamente que o Ca e $\mathrm{Mg}$ (Marschner, 1995). Essa inibição competitiva é maior entre K e Mg. Deve-se tomar muito cuidado, para garantir um balanço adequado entre esses três nutrientes, no sentido de não favorecer uma condição de deficiência induzida entre eles (Jones Jr., 1983).

Em soluções nutritivas, a concentração de $\mathrm{K}$ deve ser próxima de $200 \mathrm{mg} \mathrm{L}-1$, sendo $\mathrm{KNO}_{3}, \mathrm{~K}_{2} \mathrm{SO}_{4}$ e $\mathrm{KCl}$ as fontes geralmente mais utilizadas. Entretanto, a primeira fonte deve ser a mais utilizada, considerando-se que o potássio e o nitrogênio são os macronutrientes mais absorvidos. A utilização das outras fontes pode ocasionar um aumento na pressão osmótica da solução (Jones Jr., 1983). 
Douglas (1985) recomendou que a concentração de $\mathrm{K}$ nas soluções nutritivas deva variar entre 100 e $400 \mathrm{mg} \mathrm{L}^{-1}$, sendo que as doses maiores são utilizadas nos meses de inverno e as menores no verão.

As variações de recomendação de concentração de potássio em solução nutritiva podem ser devidas ao exposto por Douglas (1985), baseando-se no fato de que regiões com luminosidade adequada ao crescimento, as plantas de alface apresentam exigência reduzida à metade das de regiões de dias curtos e nublados.

Segundo Termine et al. (1987), a aplicação de adubos nitrogenados reduz a produção de material seco, pelo simples acúmulo de água nos tecidos. O excesso de adubação nitrogenada pode induzir o pendoamento precoce, pois causa um crescimento vegetativo rápido.

\subsubsection{Assimilação e redução do nitrato}

Os íons nitrato e nitrito estão presentes naturalmente no ambiente, como conseqüência do ciclo do nitrogênio que consiste no intercâmbio desse elemento entre a atmosfera e o solo, podendo sofrer modificações profundas, decorrentes das atividades agricolas $e$ industriais do homem. Assim sendo, a decomposição de materiais orgânicos e a utilização de fertilizantes nitrogenados, entre outros fatores, podem exercer um papel importante como fonte desses ions (Araújo \& Midio, 1989).

$\mathrm{O}$ nitrato é, freqüentemente, a principal fonte de nitrogênio disponivel para as plantas (Campbell, 1988; Marschner, 1995), mas antes de ser metabolizado, precisa ser reduzido para amônio $\left(\mathrm{NH}_{4}^{+}\right)$no processo chamado redução do nitrato e, após ser incorporado em 
aminoácidos, proteínas e outras moléculas orgânicas nitrogenadas (Hopkins, 1995). A redução do nitrato consiste de duas etapas: a redução do nitrato até nitrito e a redução do nitrito até amônio (Rao \& Rains, 1976). As duas enzimas envolvidas nesse processo são a redutase do nitrato e a redutase do nitrito (Rufty et al. 1982).

A primeira etapa da redução do nitrato até nitrito no citoplasma é catalizada pela redutase do nitrato e pode ser esquematizada pela equação (Hopkins, 1995):

$$
2 \mathrm{H}^{+}+\mathrm{NO}_{3}^{-}+2 \mathrm{e}^{-} \rightarrow \mathrm{NO}_{2}^{-}+\mathrm{H}_{2} \mathrm{O}
$$

A segunda etapa, de nitrito até amônio $\left(\mathrm{NH}_{4}^{+}\right)$, é realizada pela enzima redutase do nitrito, nos cloroplastos e, pode ser assim esquematizada (Hopkins, 1995):

$$
8 \mathrm{H}^{+}+\mathrm{NO}_{2}^{-}+6 \mathrm{e}^{-} \rightarrow \mathrm{NH}_{4}^{+}+2 \mathrm{H}_{2} \mathrm{O}
$$

A atividade da redutase do nitrato pode ser inibida ou suprimida completamente, pelo amônio e certos ácidos orgânicos (Srivastava, 1980). Em raizes, o efeito inibitório do amônio parece ser devido à acidificação da rizosfera, que está relacionada com a absorção de amônio (Mengel \& Kirkby, 1987).

O nitrito, em condições normais, raramente acumula-se nas plantas, provavelmente devido à presença nos cloroplastos, de altos niveis da enzima redutase do nitrito, que reduz o nitrito até amônio. Essa redução de nitrato até amônio pode ocorrer nas raízes ou na parte aérea. Quando o fornecimento de nitrato pelo solo ou pela solução nutritiva for pequeno, a redução ocorre principalmente nas raizes, mas quando esse nivel de suprimento aumentar significativamente, ocorre 
uma translocação de nitrato para a parte aérea, havendo uma maior redução de nitrato nessa parte da planta (Marschner, 1995).

A maior parte do nitrato é assimilado na parte aérea, em tecidos de crescimento ou nas folhas novas, onde os aminoácidos são sintetizados no citoplasma e armazenados nos vacúolos, mantendo cátions e ânions em equilíbrio com o pH intracelular. Os excessos desses solutos osmóticos, formados nos tecidos da parte aérea podem ser removidos para os vacúolos das células através de uma forma osmoticamente inativa (precipitação na forma de oxalato de cálcio); serem retranslocados junto com cátions do floema para áreas de crescimento, ou ser retranslocados na forma de malato (Ozbun et al. 1965; Marschner, 1995).

O nitrato é armazenado nos vacúolos pois amônio é tóxico para as plantas, mesmo em quantidades pequenas. A formação de aminoácidos é o principal caminho para a desintoxicação dos íons $\mathrm{NH}_{4}{ }^{+}$ absorvidos pelas raizes. Essa absorção de amônio pelas raízes requer uma grande quantidade de carboidratos, devido à necessidade de esqueletos de carbono para a sintese de aminoácidos (Marschner, 1995). 


\section{MATERIAL E MÉTODOS}

\subsection{Condições experimentais}

O experimento foi conduzido na casa-de-vegetação do Setor de Nutrição Mineral de Plantas - Departamento de Química, da Escola Superior de Agricultura "Luiz de Queiroz" (ESALQ), Piracicaba - SP (220 $42^{\prime} 30^{\prime \prime} \mathrm{S}, 47038^{\prime} \mathrm{W}, 546 \mathrm{~m}$ ), em estrutura própria para a técnica do fluxo laminar de solução (NFT), entre os dias 06 e 29 de abril de 1998. Os valores de temperatura e de umidade relativa do ar, tomados na casade-vegetação, constam do anexo A.

A estrutura para o cultivo das plantas de alface constou de uma casa-de-vegetação, com cobertura plástica, sob a qual foram montadas as bancadas. Instalou-se bancadas sobre cavaletes metálicos com 0,8 $\mathrm{m}$ de altura, sobre os quais foram colocados canais de PVC (Policloreto de vinila) aditivado, com seção triangular, com $10 \mathrm{~cm}$ de base e $5 \mathrm{~cm}$ de altura. Nesses canais, foram feitos furos com $5 \mathrm{~cm}$ de diâmetro e com espaçamento de $25 \mathrm{~cm}$ entre furos. Sobre esses canais foi instalada uma camada de ISOPOR ${ }^{\circledR}$ com $1,5 \mathrm{~cm}$ de espessura, também furada, tendo por finalidade apoiar as plantas e proporcionar um isolamento térmico dos canais. Instalou-se três bancadas com oito canais, mais dois canais nas extremidades de cada bancada, como bordaduras.

Os canais foram colocadas com a sua furação desencontrada, possibilitando um espaçamento entre as plantas de $25 \mathrm{~cm}$ e 
entre os canais de $18 \mathrm{~cm}$, caracterizando um espaçamento na forma quincôncio (losango), como pode ser observado na Figura 1.

Os canais tinham $2,6 \mathrm{~m}$ de comprimento e cada canal era uma parcela experimental, alojando 10 plantas. Cada canal teve um sistema de injeção de solução nutritiva (Figura 2A), coleta (Figura 2B), armazenamento e bombeamento da solução nutritiva individualizado. Os canais foram instalados com uma declividade de $2 \mathrm{~cm} \mathrm{~m}^{-1}$, possibilitando o retorno das soluções nutritivas para os seus depósitos de origem, através de um sistema de coleta, composto por um funil e um tubo individual. Como depósitos das soluções nutritivas, foram utilizados reservatórios de polietileno (galões plásticos) com capacidade para $20 \mathrm{~L}$. Na parte inferior desses reservatórios, foi acoplada uma bomba, tipo centrifuga de eixo horizontal e simples estágio, marca ENXUTA $^{\circledR}$, na qual adaptou-se um registro e, com isso, regulou-se para se ter uma vazão de $0,5 \mathrm{~L} \mathrm{~min}{ }^{-1}$ em cada canal.

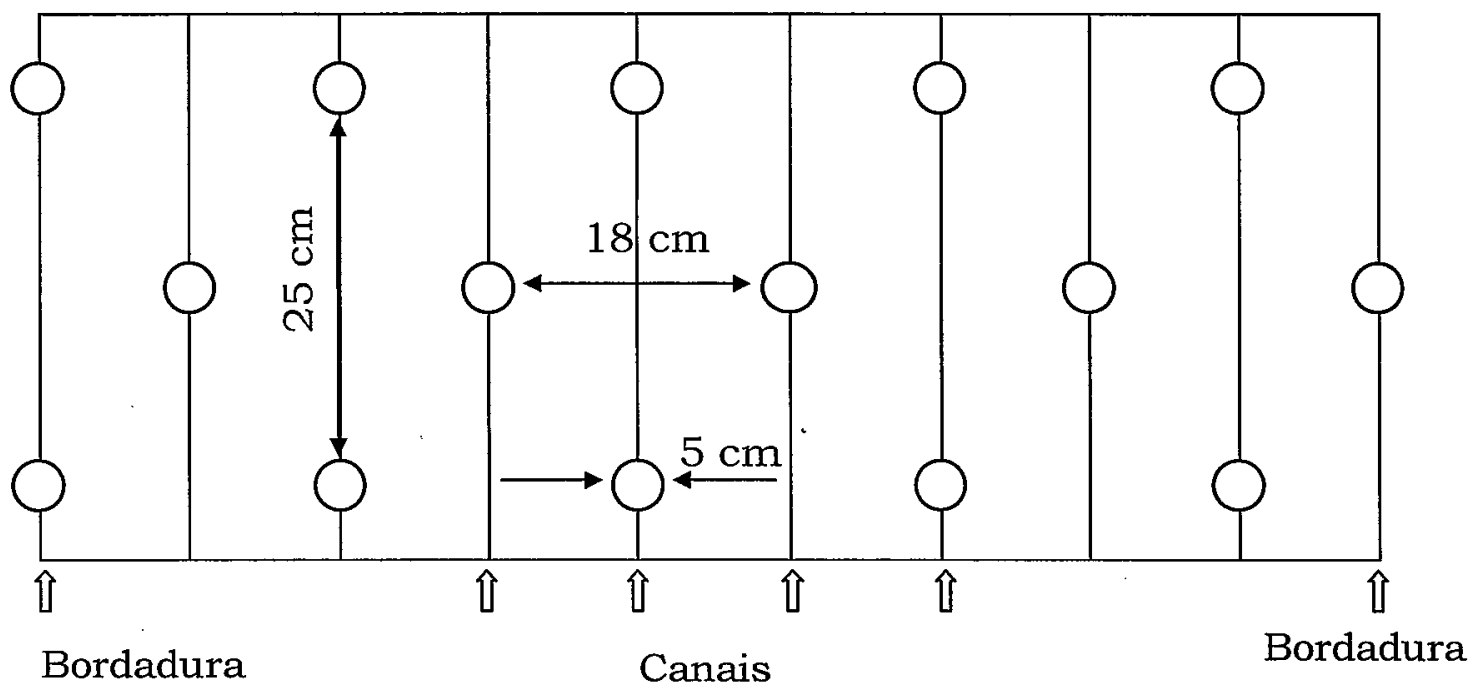

FIGURA 1 - Esquema de disposição dos canais nas bancadas e do espaçamento dos furos que alojaram as plantas de alface (sem escala). 

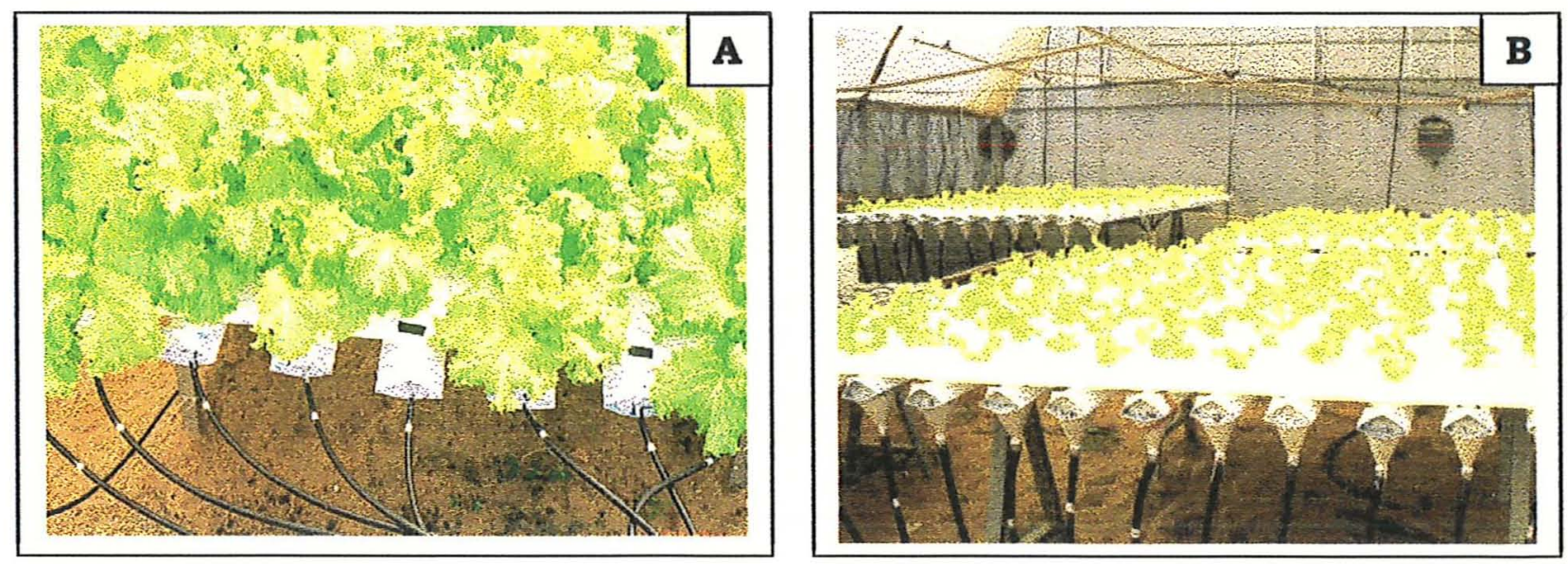

FIGURA 2 - Disposição dos canais nas bancadas e do espaçamento dos furos que alojaram as plantas de alface. A - Injeção da solução nutritiva, B - Coleta da solução nutriva.

\subsection{Delineamento experimental, tratamentos e condução do experimento}

O experimento foi realizado utilizando-se o delineamento experimental inteiramente casualizado, com duas cultivares de alface (Vera e Marisa), quatro doses fixas de potássio e nitrogênio e três repetições. Todos os nutrientes foram mantidos constantes, exceto o nitrogênio, que acompanhou o potássio, em função da utilização de $\mathrm{KNO}_{3}$ comercial (Tabela 1). Os tratamentos, com as doses conjuntas de nitrogênio e potássio expressos em $\mathrm{mg} \mathrm{L}^{-1}$, foram de:

1) 220 de $\mathrm{N}$ e 160 de $\mathrm{K}$;

2) 240 de $\mathrm{N}$ e 220 de $\mathrm{K}$;

3) 260 de $\mathrm{N}$ e $280 \mathrm{de} \mathrm{K}$;

4) 280 de $\mathrm{N}$ e 340 de $\mathrm{K}$.

As soluções nutritivas foram preparadas utilizando-se água 
potável, cujo valor de $\mathrm{pH}$ foi de 6,5 e condutividade elétrica de $0,17 \mathrm{mS}$ $\mathrm{cm}^{-1}$. As concentrações de nutrientes na água, em $\mathrm{mg} \mathrm{L}^{-1}$, foram: 3,8 de N; 0,6 de P; 0 de K; 19,9 de Ca; 4,2 de Mg; 6,4 de S; 0,06 de B; 0,03 de $\mathrm{Cu} ; 0,02$ de $\mathrm{Fe} ; 0$ de $\mathrm{Mn}$ e 0,14 de $\mathrm{Zn}$, que não foram consideradas quando se preparou as soluções nutritivas.

Tabela 1 - Volumes das soluções estoque utilizados no preparo das soluções nutritivas, em função das doses conjuntas de nitrogênio e potássio ${ }^{1}$.

\begin{tabular}{|c|c|c|c|c|c|}
\hline \multicolumn{6}{|c|}{ Doses dos nutrientes (mg L $\left.{ }^{-1}\right)$} \\
\hline \multicolumn{2}{|l|}{$\mathrm{N}$} & 220 & 240 & 260 & 280 \\
\hline \multicolumn{2}{|l|}{$\mathrm{K}$} & 160 & 220 & 280 & 340 \\
\hline \multicolumn{3}{|c|}{ Solução estoque } & \multicolumn{3}{|c|}{ Volume $\left(\left(\mathrm{mL}(20 \mathrm{~L})^{-1}\right)\right.$} \\
\hline $\mathrm{KNO}_{3}$ & M & 82 & 113 & 143 & 174 \\
\hline $\mathrm{NH}_{4} \mathrm{NO}_{3}$ & M & 2 & 1 & - & - \\
\hline $\mathrm{NH}_{4} \mathrm{H}_{2} \mathrm{PO}_{4}(\mathrm{MAP})$ & $\mathrm{M}$ & 26 & 26 & 26 & 26 \\
\hline $\mathrm{MgSO}_{4} \cdot 7 \mathrm{H}_{2} \mathrm{O}$ & $\mathrm{M}$ & 40 & 40 & 40 & 40 \\
\hline $\mathrm{Ca}\left(\mathrm{NO}_{3}\right)_{2} \cdot 4 \mathrm{H}_{2} \mathrm{O}$ & $\mathrm{M}$ & 101 & 101 & 101 & 101 \\
\hline Micronutrientes $^{(2)}$ & & 20 & 20 & 20 & 20 \\
\hline $\mathrm{Fe} \mathrm{EDTA}^{(3)}$ & & 20 & 20 & 20 & 20 \\
\hline
\end{tabular}

(M) - Concentração da solução estoque (Molar $\left.=1 \mathrm{~mol} \mathrm{~L}^{-1}\right)$.

1 Concentração de macronutrientes na solução nutritiva de Sarruge (1975) em mg L-1: N (210); $\mathrm{P}(31)$; K (234); Ca (200); Mg (48) e S (64).

2 Composição da solução de micronutrientes em g L-1: $\mathrm{H}_{3} \mathrm{BO}_{3}(2,86) ; \mathrm{MnCl}_{2}$. $4 \mathrm{H}_{2} \mathrm{O}(1,81)$;

$\mathrm{ZnCl}_{2}(0,10) ; \mathrm{CuCl}_{2}(0,04)$ e $\mathrm{H}_{2} \mathrm{MoO}_{4} \cdot \mathrm{H}_{2} \mathrm{O}(0,02)$.

3 Procedimento para preparação de 1 litro da solução de Fe-EDTA: Dissolveram-se 26,2 g de EDTA dissódico em $286 \mathrm{~mL}$ de $\mathrm{NaOH}(\mathrm{M})$, após dissolveram-se $24,0 \mathrm{~g}$ de $\mathrm{FeSO}_{4} \cdot 7 \mathrm{H}_{2} \mathrm{O}$, arejando-se por uma noite e completando-se o volume com água deionizada.

O volume de solução foi de 2 litros por planta, durante todo o periodo experimental, totalizando 20 litros de solução nutritiva por parcela. Durante o periodo diurno, a solução foi recirculada em intervalos de 15 minutos por periodos de 15 minutos parada e, durante o período noturno, com periodo de 3 horas parada por intervalos de 15 
minutos recirculando. Esse controle do periodo noturno e diurno foi realizado por um temporizador ("timer"), equipado com sensor fotoelétrico.

$\mathrm{O}$ pH das soluções foi medido, e ajustado diariamente para 6,0; utilizando-se solução $1 \mathrm{~N}$ de $\mathrm{NaOH}$ ou $\mathrm{HCl}$, de acordo com a necessidade. Foram utilizadas duas cultivares de alface (Lactuca sativa L.) Vera e Marisa, que são do tipo repolhuda crespa, ambas recomendadas para as condições de verão, pois apresentam baixa incidência de pendoamento, podendo ser cultivadas durante todo $o$ ano.

A semeadura foi realizada em bandejas de ISOPOR ${ }^{\circledR}$ com 144 células, tendo como substrato a vermiculita. As bandejas permaneceram flutuando em água até a emergência das plântulas. Em solução nutritiva diluída ( $1 / 2$ solução normal) por uma semana e após em solução nutritiva normal. A solução foi recirculada de maneira semelhante à dos tratamentos, porém com periodos de 30 minutos durante o dia e a cada 3 horas durante a noite por um intervalo de 15 minutos funcionando. A composição da solução nutritiva (normal) utilizada para a produção das mudas foi baseado em Sarruge (1975), cuja concentração em $\mathrm{mg} \mathrm{L}^{-1}$, foi a seguinte: 210 de N; 31 de P; 234 de K; 200 de Ca; 48 de Mg; 65 de S; 5 de $\mathrm{Fe} ; 0,02$ de $\mathrm{Cu}$; 0,5 de B; 0,01 de Mo; 0,02 de $\mathrm{Zn}$ e 0,5 de Mn.

O transplante para as bancadas ocorreu quando as mudas apresentaram 4 a 5 folhas bem desenvolvidas, o que foi alcançado aos 30 dias após a semeadura.

\subsection{Amostragens e determinações}

As cinco plantas centrais de cada parcela foram coletadas no final do ciclo (17 dias após o transplante), separadas em parte aérea e 
sistema radicular. As raízes foram lavadas com $\mathrm{HCl} 0,1 \mathrm{~N}$ e enxaguadas com água destilada para retirar os nutrientes que porventura estivessem aderidos a elas. Após a lavagem, as raizes foram envolvidas com papel absorvente para retirar o excesso de água.

Para a determinação da massa de material fresco da parte aérea e das raízes de cada planta foi utilizada uma balança eletrônica com duas casas de precisão marca "OHAUS", modelo "Precision Plus". Esta balança foi conectada, via cabo, à porta serial de um computador IBM/PC, pelo protocolo RS232. Os valores emitidos pela balança eram automaticamente tabulados em uma planilha do programa Microsoft Excel para Windows 95 v7.0 (Microsoft Corporation, 1995) através do programa WEDGE v1.2 (T.A.L. Technologies Incorporated, 1997). Após essa determinação, as amostras foram acondicionadas em sacos de papel para a secagem em estufa com circulação forçada de ar a $65^{\circ} \mathrm{C}$, até atingirem massa constante. Efetuou-se então nova pesagem, segundo o método descrito acima, para avaliar-se a massa do material seco e, após, as amostras foram moídas em conjunto (cinco plantas) utilizando-se moinho tipo Wiley e acondicionadas em sacos de polietileno, para serem submetidas à análise química. Foram analisados os teores de macronutrientes, nas raizes e na parte aérea, conforme a metodologia analitica descrita por Sarruge \& Haag (1974).

Para a determinação do nitrato foi utilizado $0,5 \mathrm{~g}$ da massa do material seco da parte aérea das plantas, o qual foi extraído segundo Peoples et al. (1989) e determinado conforme a metodologia descrita por Cataldo et al. (1975). 


\subsection{Análises estatisticas}

Os resultados da massa do material fresco e seco da parte aérea e da planta inteira, do consumo de solução nutritiva, do teor de nitrato, a concentração e a quantidade de nutrientes nos tecidos, foram submetidos à análise de variância.

Quando houve significância para a interação entre tratamentos e cultivares, prosseguiu-se a análise estatística com o cálculo das regressões polinomiais e de suas equações, com $\mathrm{P}<0,05$. Para cada interação testada, adotaram-se as equações de regressão com o maior coeficiente de determinação $\left(R^{2}\right)$. Quando a interação entre os tratamentos e as cultivares não foi significativa, mas o efeito dos tratamentos sim, calculou-se a regressão para os tratamentos para as duas cultivares em conjunto. Nesse caso, apresentou-se apenas uma única curva, que representa o comportamento médio dos tratamentos para as duas cultivares. Foram consideradas apenas as interações com coeficiente de determinação maior que 0,40 .

Aplicou-se, também, o teste " $\mathrm{t}$ " de Student $(\mathrm{P}<0,05)$ para as variáveis qualitativas (cultivares) com o objetivo de verificar-se as diferenças estatísticas entre as mesmas para os seguintes parâmetros: consumo de solução nutritiva, massa do material fresco, massa do material seco, teor de nitrato, concentração e a quantidade de nutrientes no tecido.

Todas as análises estatísticas foram realizadas utilizando-se o programa estatístico SAS-System for Windows release 6.11 (SAS, Institute Incorporation, 1996). 


\section{RESULTADOS E DISCUSSÃo}

\subsection{Consumo de solução nutritiva}

Durante o periodo experimental, a cultivar Marisa apresentou uma tendência numérica de consumo de solução nutritiva superior em relação a cultivar Vera. Apesar de não haver diferença significativa entre os tratamentos estudados, houve diferença significativa entre as duas cultivares nos tratamentos cujas doses conjuntas de nitrogênio e potássio foram: 240 e 220; 280 e $340\left(\mathrm{mg} \mathrm{L}^{-1}\right)$, respectivamente (Tabela 2).

A não constatação de diferença significativa no consumo de solução nutritiva entre as doses de nutrientes, contrariam os resultados encontrados por Koefender (1996), que observou um maior consumo de solução nutritiva quando a concentração de nutrientes na solução era mais alto. Isso pode ser explicado, em função do número de plantas utilizadas por esse autor, 135 plantas por tratamento, enquanto que neste experimento trabalhou-se com apenas 10 plantas por repetição.

Isso sugere que o consumo de solução nutritiva, em função das doses de nutrientes, necessita ser melhor esclarecido em estudos específicos comparando-se, por exemplo, números de plantas diferentes por parcela. 
Tabela 2 - Consumo total de solução nutritiva (por dez plantas) durante o periodo experimental, por duas cultivares de alface (Marisa e Vera). Média de três repetiçōes.

\begin{tabular}{|c|c|c|c|}
\hline \multicolumn{2}{|c|}{ Tratamento } & \multirow{2}{*}{\multicolumn{2}{|c|}{$\begin{array}{c}\text { Consumo de solução } \\
\text { (L) }\end{array}$}} \\
\hline $\mathrm{N}$ & $\mathrm{K}$ & & \\
\hline \multicolumn{2}{|c|}{$\left(\mathrm{mg} \mathrm{L}^{-1}\right)$} & Marisa & Vera \\
\hline 220 & 160 & $23,63 \mathrm{a}$ & $19,50 \mathrm{a}$ \\
\hline 240 & 220 & $24,30 \mathrm{a}$ & $19,77 \mathrm{~b}$ \\
\hline 260 & 280 & $23,03 \mathrm{a}$ & $22,90 \mathrm{a}$ \\
\hline 280 & 340 & $23,30 \mathrm{a}$ & $18,07 \mathrm{~b}$ \\
\hline
\end{tabular}

\subsection{Produção de material fresco}

A análise de variância para a produção de material fresco da parte aérea $(\mathrm{MFPA})$ revelou significância $(\mathrm{P}<0,05)$ para a interação entre as duas cultivares estudadas $\mathrm{e}$ as doses conjuntas de nitrogênio e potássio.

No desdobramento da interação entre cultivares e doses de potássio, a resposta do MFPA de cada cultivar foi representada através das equações apresentadas na Figura 3. Para a cultivar Marisa, a resposta às doses de nitrogênio e de potássio na solução seguiu o modelo linear, no qual não se alcançou o ponto de produção máxima. A cultivar Vera respondeu segundo um modelo quadrático, e o ponto de produção máxima de $164,66 \mathrm{~g}$, foi atingido com a dose conjunta estimada de $259,7 \mathrm{mg} \mathrm{L}^{-1}$ de $\mathrm{N}$ e de $279,2 \mathrm{mg} \mathrm{L}^{-1}$ de $\mathrm{K}$ na solução nutritiva (Figura 3). 


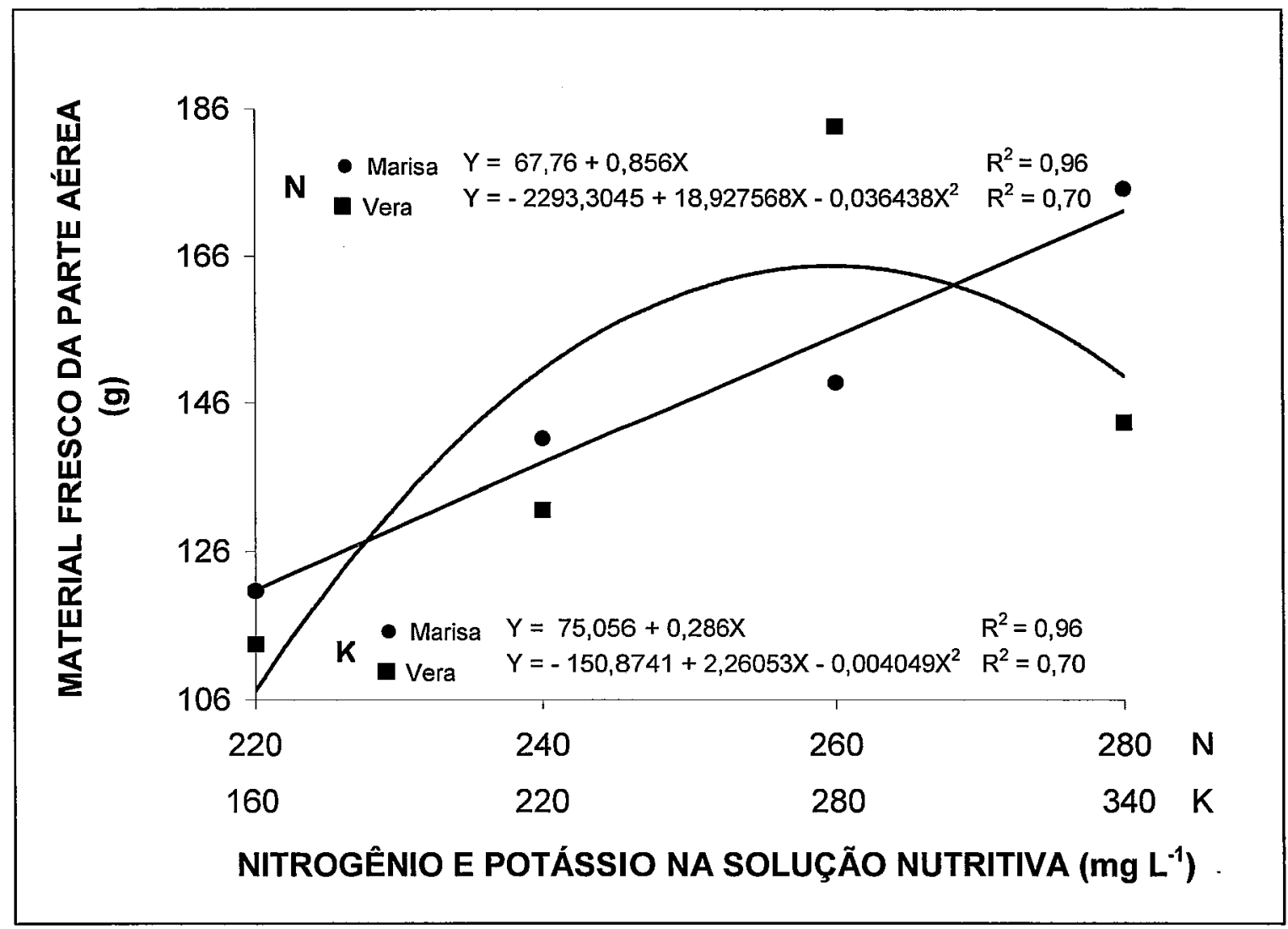

FIGURA 3 - Produção de material fresco (por planta) da parte aérea de duas cultivares de alface (Marisa e Vera) em função das doses conjuntas de nitrogênio e potássio nas soluções nutritivas. Média de três repetições.

$\mathrm{Na}$ comparação de cultivares, houve diferença significativa na dose $260 \mathrm{mg} \mathrm{L}^{-1}$ de $\mathrm{N}$ e $280 \mathrm{mg} \mathrm{L}^{-1}$ de $\mathrm{K}$ e na dose $280 \mathrm{mg} \mathrm{L}^{-1}$ de $\mathrm{N}$ e 340 $\mathrm{mg} \mathrm{L}^{-1}$ de $\mathrm{K}$ nas soluções nutritivas (Tabela 3). 
Tabela 3 - Produção de material fresco (por planta) da parte aérea, das raizes e da planta inteira por duas cultivares de alface (Marisa e Vera) em função das doses conjuntas de nitrogênio e potássio nas soluções nutritivas. Média de três repetições.

\begin{tabular}{|c|c|c|c|c|c|c|c|}
\hline \multicolumn{2}{|c|}{ Tratamento } & \multicolumn{6}{|c|}{ Produção de material fresco $(\mathrm{g})$} \\
\hline $\mathrm{N}$ & $\mathrm{K}$ & \multicolumn{2}{|c|}{ Parte aérea } & \multicolumn{2}{|c|}{ Raîzes } & \multicolumn{2}{|c|}{ Planta inteira } \\
\hline \multicolumn{2}{|c|}{$\left(\mathrm{mg} \mathrm{L}^{-1}\right)$} & Marisa & Vera & Marisa & Vera & Marisa & Vera \\
\hline 220 & 160 & $120,7 \mathrm{a}$ & $113,5 \mathrm{a}$ & $10,5 \mathrm{a}$ & $9,3 \mathrm{a}$ & $131,2 \mathrm{a}$ & $122,8 \mathrm{a}$ \\
\hline 240 & 220 & $141,2 \mathrm{a}$ & 131,6 a & $11,9 \mathrm{a}$ & $11,0 \mathrm{a}$ & $153,1 \mathrm{a}$ & $142,6 \mathrm{a}$ \\
\hline 260 & 280 & $148,8 \mathrm{a}$ & $183,6 \mathrm{~b}$ & $13,1 \mathrm{a}$ & $16, \mathrm{ob}$ & $161,9 \mathrm{a}$ & $199,6 \mathrm{~b}$ \\
\hline 280 & 340 & $175,3 \mathrm{a}$ & $143,4 \mathrm{~b}$ & $15,3 \mathrm{a}$ & $12,6 \mathrm{~b}$ & 190,6 a & $156,0 \mathrm{~b}$ \\
\hline
\end{tabular}

Koefender (1996), em estudo realizado no mesmo local deste experimento, verificou uma produção de MFPA de 183,93 g por planta para a cultivar Verônica, com a utilização conjunta de $196,7 \mathrm{mg} \mathrm{L}^{-1}$ de $\mathrm{N}$ e 231,3 $\mathrm{mg} \mathrm{L}^{-1}$ de $\mathrm{K}$ na solução nutritiva. Esse resultado é maior que os obtidos neste experimento para a mesmas doses, porém isso pode ser atribuído ao maior periodo experimental (30 dias após o transplante) e à cultivar utilizada.

A produção de material fresco de raizes variou significativamente $(\mathrm{P}<0,05)$ com as doses de nitrogênio e de potássio. A cultivar Vera apresentou produção máxima de $14,27 \mathrm{~g}$ na dose conjunta estimada de 262,1 e 285,5 $\mathrm{mg} \mathrm{L}^{-1}$ de nitrogênio e de potássio, respectivamente, na solução nutritiva. Por outro lado, a cultivar Marisa apresentou resposta similar aos resultados da produção de material fresco da parte aérea, ou seja, seguiu um modelo linear, no qual não se alcançou o ponto de produção máxima (Figura 4). 


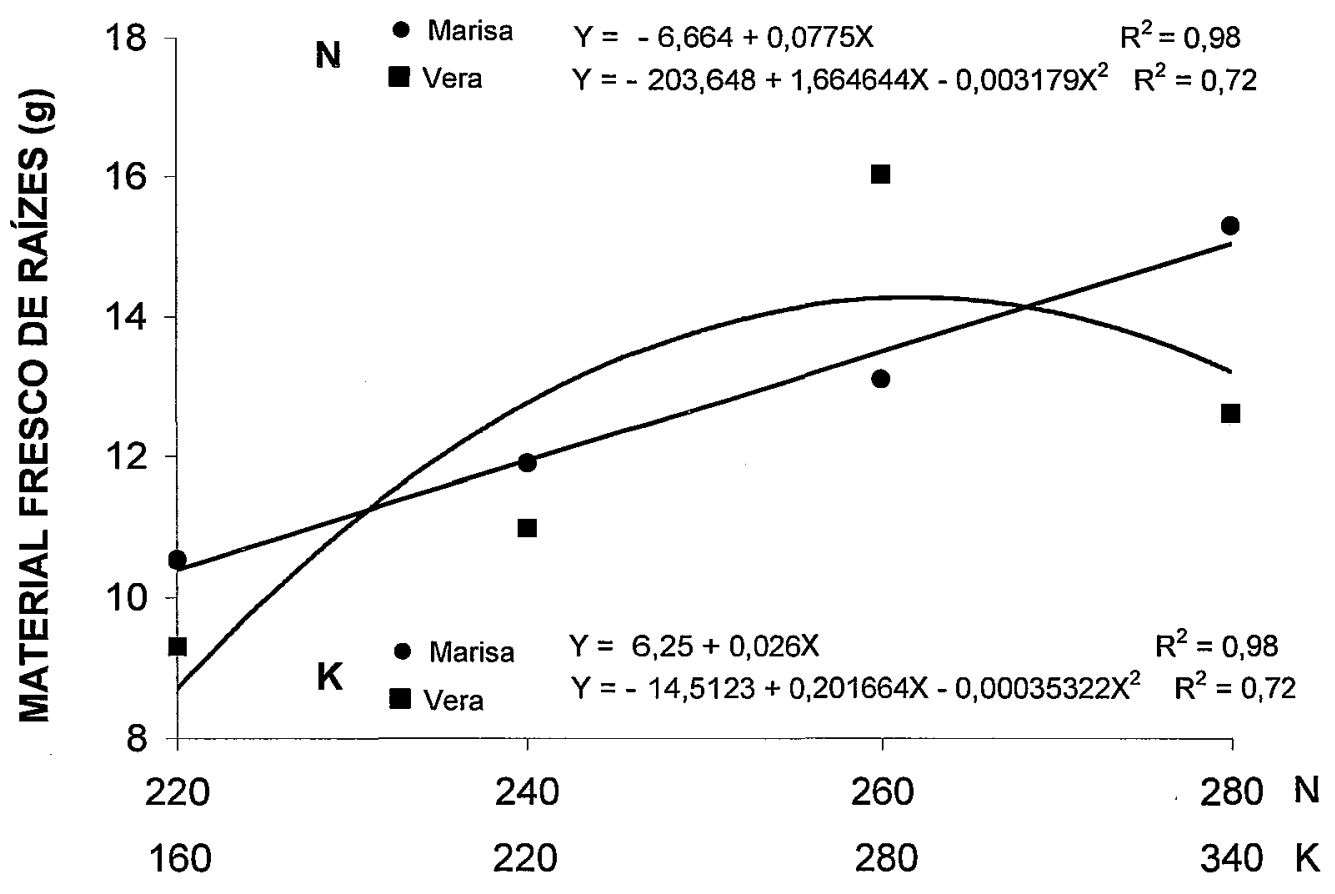

NITROGÊNIO E POTÁSSIO NA SOLUÇÃO NUTRITIVA (mg L L $\left.{ }^{-1}\right)$

FIGURA 4 - Produção de material fresco (por planta) de raizes de duas cultivares de alface (Marisa e Vera) em função das doses conjuntas de nitrogênio e potássio nas soluções nutritivas. Média de três repetições.

Na Figura 4 observa-se as produções de material fresco (MF) da planta inteira de alface.

Da mesma forma que para a produção de material fresco da parte aérea (Figura 3), e das raízes (Figura 4) a cultivar Marisa apresentou uma resposta segundo um modelo linear, para a produção do MF da planta inteira (Figura 5). 


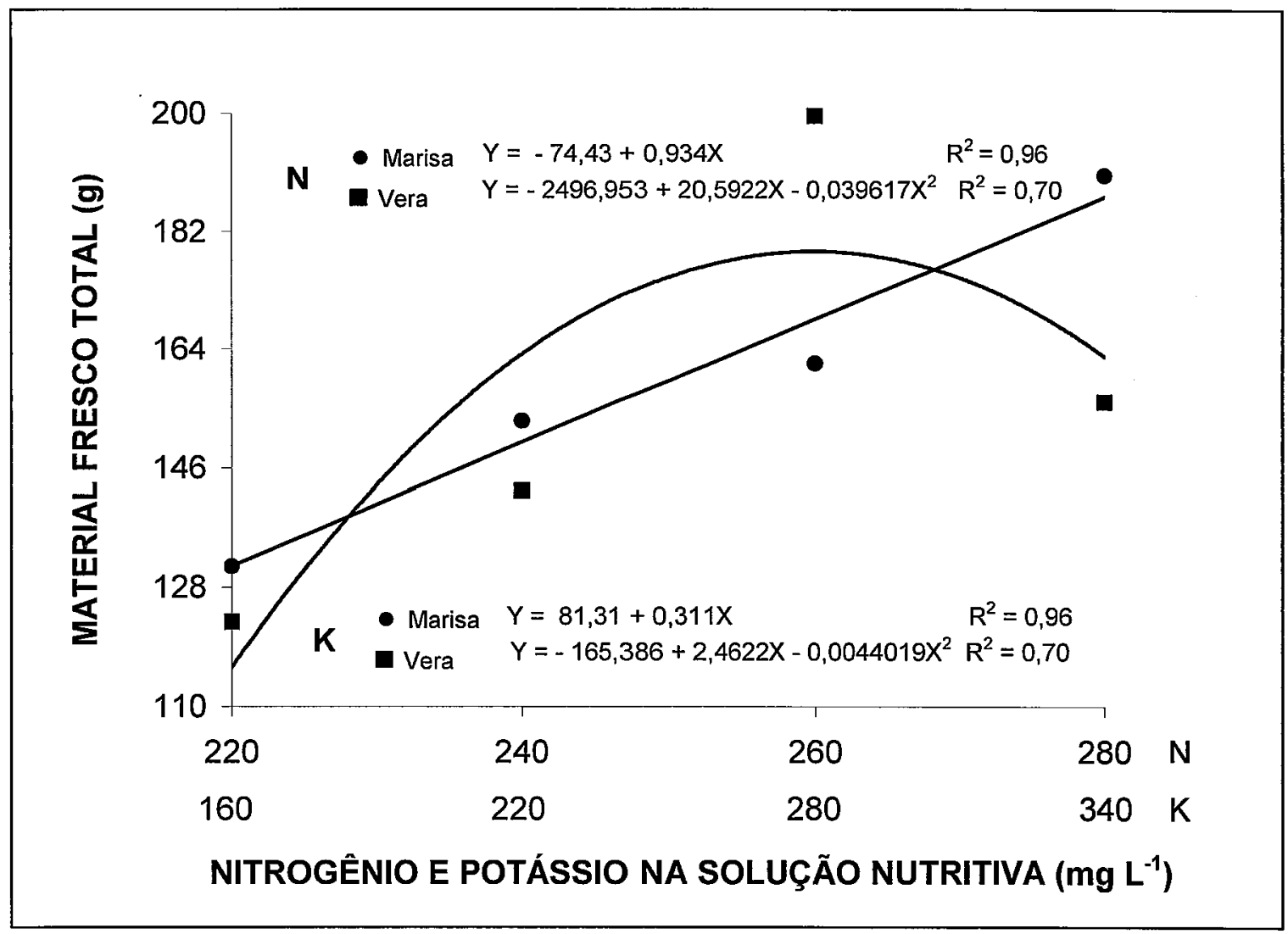

FIGURA 5 - Produção de material fresco (por planta) da planta inteira de duas cultivares de alface (Marisa e Vera) em função das doses conjuntas de nitrogênio e potássio nas soluções nutritivas. Média de três repetições.

A produção de $186,7 \mathrm{~g}$ da planta foi conseguida com as doses conjuntas de $280 \mathrm{mg} \mathrm{L}^{-1}$ de $\mathrm{N}$ e $340 \mathrm{mg} \mathrm{L}^{-1}$ de $\mathrm{K}$. A produção da planta inteira é regulada principalmente pela produção da parte aérea, pois ela é responsável pela maior fração do MF da alface (Koefender, 1996).

Para a cultivar Vera, os resultados do material fresco da planta inteira foram melhor explicados por um modelo quadrático (Figura 5). O ponto de produção máxima de material fresco da planta inteira de 178,92 g por planta foi estimado com o emprego conjunto de $259,9 \mathrm{mg}$ $\mathrm{L}^{-1}$ de $\mathrm{N}$ e de $279,7 \mathrm{mg} \mathrm{L}^{-1}$ de $\mathrm{K}$, respectivamente, na solução nutritiva.

Zito et al. (1994), utilizando a cultivar Vitória Verde-Clara, obtiveram $122,5 \mathrm{~g}$ por planta com o tratamento mais produtivo, sendo 
inferior aos resultados encontrados nas doses mais baixas $\left(220 \mathrm{mg} \mathrm{L}^{-1}\right.$ de $\mathrm{N}$ e $160 \mathrm{mg} \mathrm{L}^{-1}$ de $\mathrm{K}$ ), que produziu $131,2 \mathrm{~g}$ por planta para a cultivar Marisa e 122,8 g por planta para a cultivar Vera. Costa et al. (1997), cultivando a cultivar Babá, encontraram resultados de material fresco da planta inteira ligeiramente superior $(134,8 \mathrm{~g})$, apesar de utilizarem doses conjuntas de $140 \mathrm{mg} \mathrm{L}^{-1}$ de $\mathrm{N}$ e $195 \mathrm{mg} \mathrm{L}^{-1}$ de $\mathrm{K}$ na solução nutritiva. Esses resultados, encontrados por esses autores, podem ser explicados pela maior duração do experimento (34 e 33 dias após o transplante), pelo maior volume de solução nutritiva utilizada por planta (4 litros em ambos os experimentos) e a resposta diferente da cultivar estudada por esses autores.

\subsection{Produção de material seco}

A produção de material seco da parte aérea das plantas de alface diferiu significativamente entre as duas cultivares, nos tratamentos cujas doses de nitrogênio e de potássio foram: 220 e 160; 260 e 280; 280 e $340\left(\mathrm{mg} \mathrm{L}^{-1}\right)$ nas soluções nutritivas, respectivamente. Para as raizes e para a planta inteira, houve diferença significativa entre as cultivares em todos os tratamentos (Tabela 4). 
Tabela 4 - Produção de material seco (por planta) da parte aérea, das raizes e da planta inteira por duas cultivares de alface (Marisa e Vera) em função das doses conjuntas de nitrogênio e potássio nas soluções nutritivas. Média de três repetições.

\begin{tabular}{|c|c|c|c|c|c|c|c|}
\hline \multicolumn{2}{|c|}{ Tratamento } & \multicolumn{6}{|c|}{ Produção de material seco (g) } \\
\hline $\mathrm{N}$ & $\mathrm{K}$ & \multicolumn{2}{|c|}{ Parte aérea } & \multicolumn{2}{|c|}{ Raizes } & \multicolumn{2}{|c|}{ Planta inteira } \\
\hline \multicolumn{2}{|c|}{$\left(\mathrm{mg} \mathrm{L}^{-1}\right)$} & Marisa & Vera & Marisa & Vera & Marisa & Vera \\
\hline 220 & 160 & $5,59 \mathrm{a}$ & $4,76 \mathrm{~b}$ & $0,19 \mathrm{a}$ & $0,10 \mathrm{~b}$ & $5,78 \mathrm{a}$ & $4,86 \mathrm{~b}$ \\
\hline 240 & 220 & $5,88 \mathrm{a}$ & $5,24 \mathrm{a}$ & $0,21 \mathrm{a}$ & $0,12 \mathrm{~b}$ & $6,09 \mathrm{a}$ & $5,36 \mathrm{~b}$ \\
\hline 260 & 280 & $6,15 \mathrm{a}$ & $7,59 \mathrm{~b}$ & $0,20 \mathrm{a}$ & $0,44 \mathrm{~b}$ & $6,35 a$ & $8,03 \mathrm{~b}$ \\
\hline 280 & 340 & $6,83 \mathrm{a}$ & $5,88 \mathrm{~b}$ & $0,37 \mathrm{a}$ & $0,17 \mathrm{~b}$ & $7,20 \mathrm{a}$ & $6,05 \mathrm{~b}$ \\
\hline
\end{tabular}

A produção de material seco da parte aérea (MSPA) da alface apresentou aumentos significativos $(P<0,05)$, em função das doses de nitrogênio e de potássio nas soluções nutritivas (Figura 6).

A produção máxima do MSPA de $6,7 \mathrm{~g}$ foi obtida na dose conjunta estimada de $260,4 \mathrm{mg} \mathrm{L}^{-1}$ de $\mathrm{N}$ e de $281,2 \mathrm{mg} \mathrm{L}^{-1}$ de $\mathrm{K}$ para a cultivar Vera. Para a cultivar Marisa, por ela ter se ajustado melhor a um modelo de equação linear, não foi possivel chegar-se a um ponto de produção máxima do MSPA, com as doses estudadas. 


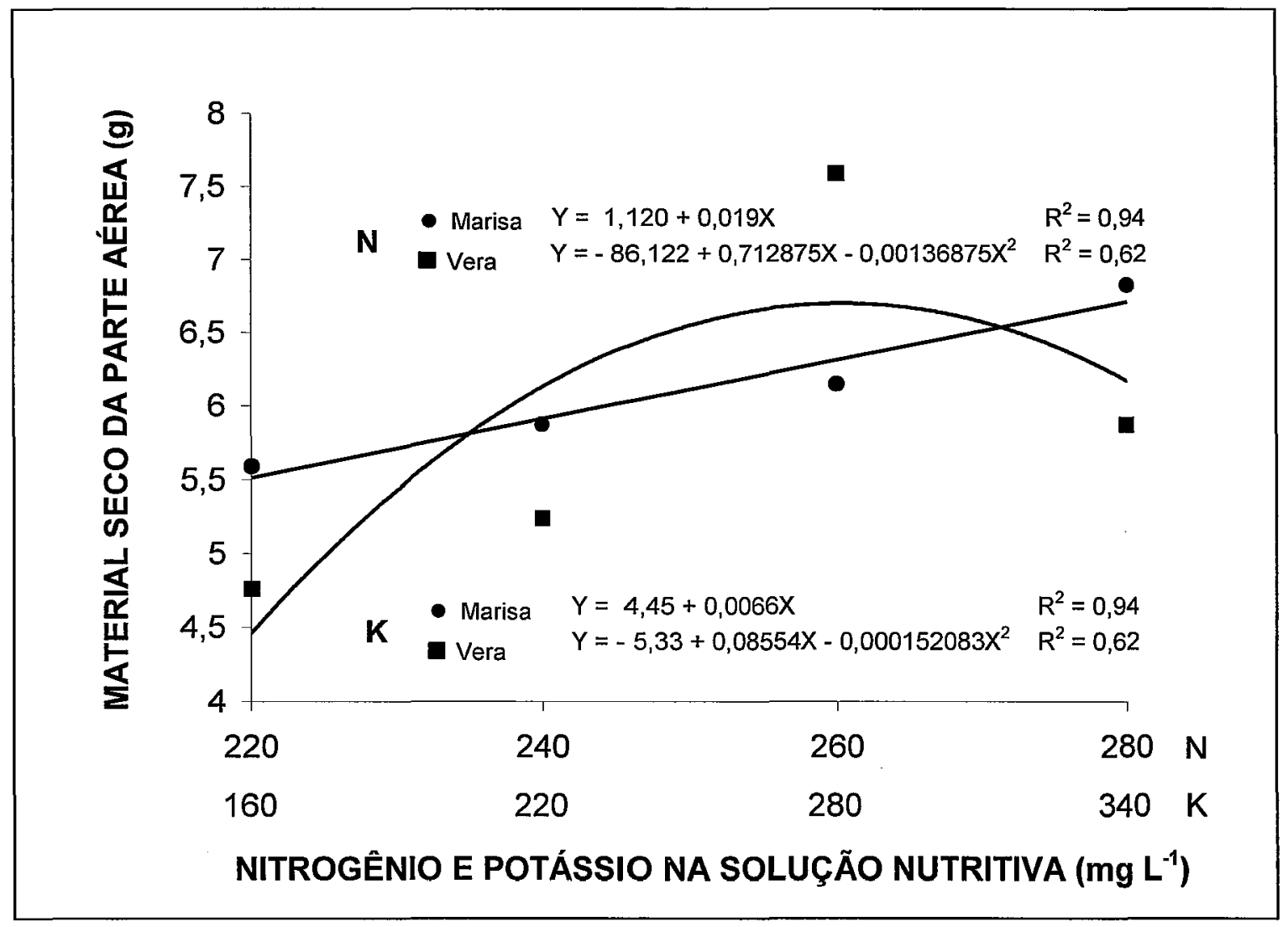

FIGURA 6 - Produção de material seco (por planta) da parte aérea de duas cultivares de alface (Marisa e Vera) em função das doses conjuntas de nitrogênio e potássio nas soluções nutritivas. Média de três repetições.

A produção de material seco de raízes apresentou também aumentos significativos, ajustando-se a uma equação linear para a cultivar Marisa e a um modelo de equação quadrática para a cultivar Vera. Para esta cultivar, a produção máxima de $0,33 \mathrm{~g}$ foi obtida na dose conjunta estimada de $257,6 \mathrm{mg} \mathrm{L}^{-1}$ de $\mathrm{N}$ e de $272,7 \mathrm{mg} \mathrm{L}^{-1}$ de $\mathrm{K}$ na solução nutritiva (Figura 7). 


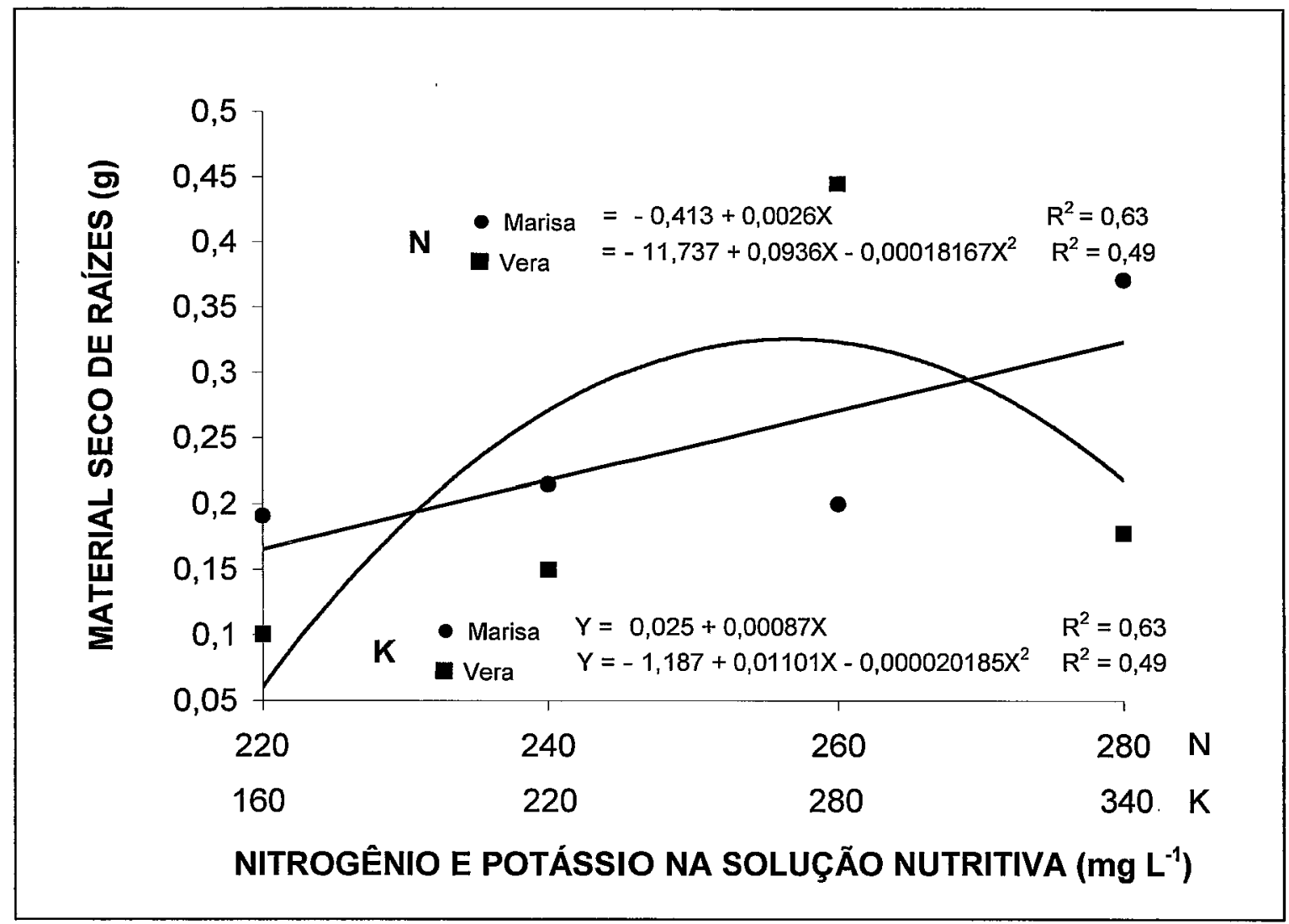

FIGURA 7 - Produção de material seco (por planta) de raizes de duas cultivares de alface (Marisa e Vera) em função das doses conjuntas de nitrogênio e potássio nas soluções nutritivas. Média de três repetições.

A Figura 8 apresenta a produção de material seco (MS) da planta inteira de alface. Observou-se interação entre as doses conjuntas de nitrogênio e potássio e as duas cultivares de alface. 


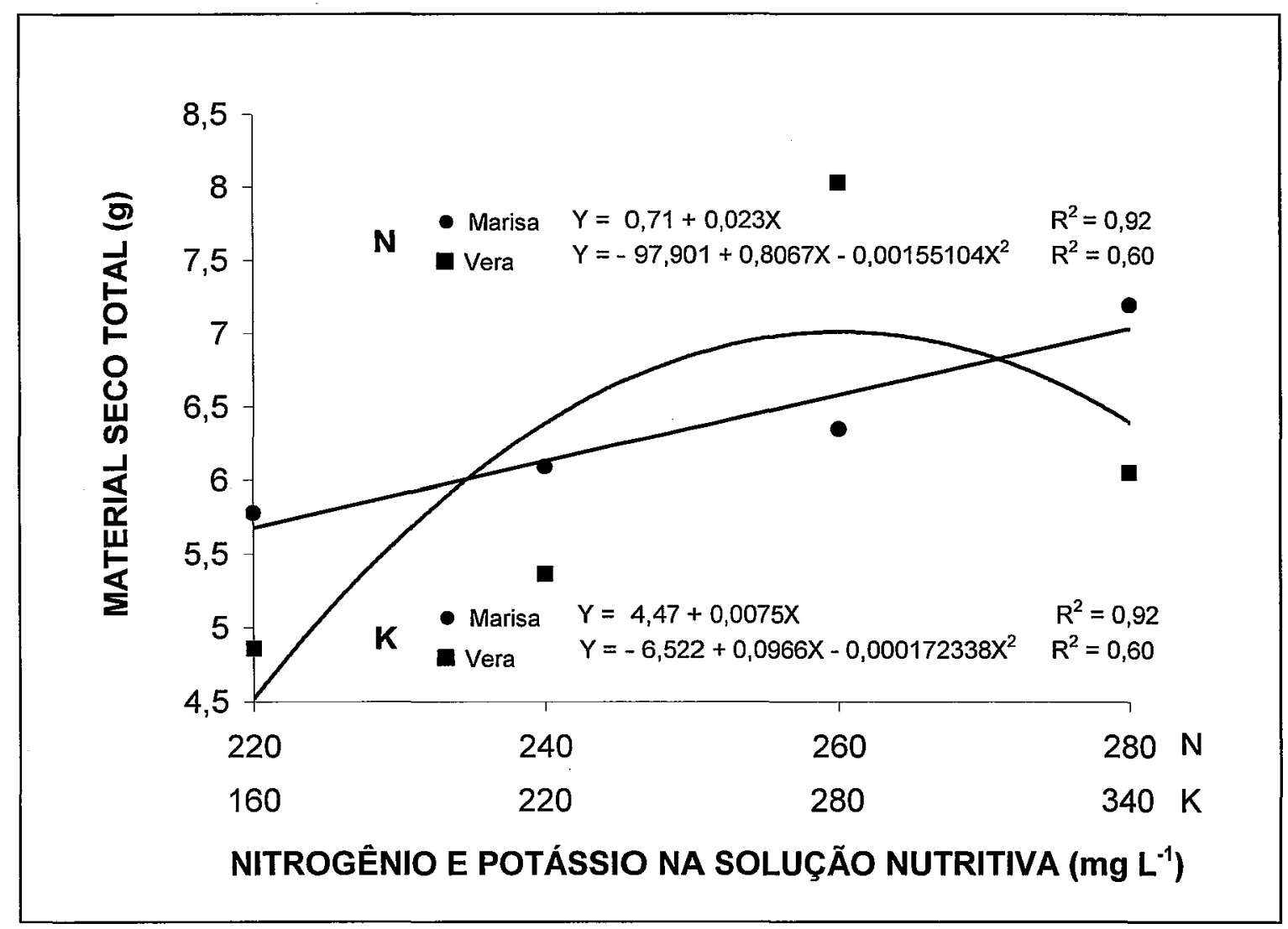

FIGURA 8 - Produção de material seco (por planta) da planta inteira de duas cultivares de alface (Marisa e Vera) em função das doses conjuntas de nitrogênio e potássio nas soluções nutritivas. Média de três repetições.

A produção máxima do MS da planta inteira de $7,01 \mathrm{~g}$ foi estimada na dose conjunta de $260,0 \mathrm{mg} \mathrm{L}^{-1}$ de $\mathrm{N}$ e de $280,2 \mathrm{mg} \mathrm{L}^{-1}$ de $\mathrm{K}$, para a cultivar Vera. Esses resultados seguiram $\circ$ mesmo comportamento dos resultados da parte aérea, inclusive com semelhança nos pontos de produção máxima (Figura 6). A cultivar Marisa também seguiu o mesmo comportamento da parte aérea (Figura 6), ajustando-se a um modelo de equação linear, não permitindo chegarse a um ponto de produção máxima do MS.

Os teores de umidade da planta inteira revelaram significância $(\mathrm{P}<0,05)$ para a interação entre as duas cultivares estudadas e as doses estudadas. Entre cultivares não houve diferença significativa nas doses 
testadas (Tabela 5). O comportamento dessa caracteristica foi semelhante para a quantidade de umidade das raizes e da parte aérea, que também não diferiu estatisticamente entre os tratamentos e entre as cultivares.

Tabela 5 - Teor de umidade da planta inteira (por planta) de duas cultivares de alface (Marisa e Vera). Média de três repetições.

\begin{tabular}{|c|c|c|c|c|}
\hline \multicolumn{2}{|c|}{ Tratamento } & \multirow{2}{*}{\multicolumn{3}{|c|}{$\frac{\text { Umidade }}{\left(\mathrm{g} \mathrm{kg}^{-1}\right)}$}} \\
\hline $\mathrm{N}$ & $\mathrm{K}$ & & & \\
\hline \multicolumn{2}{|c|}{$\left(\mathrm{mg} \mathrm{L}^{-1}\right)$} & Marisa & Vera & \\
\hline 220 & 160 & 956,0 & 960,4 & \\
\hline 240 & 220 & 960,2 & 962,4 & $\cdot$ \\
\hline 260 & 280 & 960,8 & 959,7 & \\
\hline 280 & 340 & 962,2 & 961,2 & \\
\hline
\end{tabular}

Os resultados da produção de MS da planta inteira encontrados neste experimento, mesmo nas doses mais altas de $\mathrm{N}$ e $\mathrm{K}$, foram inferiores aos de Furlani (1997), que utilizando conjuntamente $195 \mathrm{mg}$ $\mathrm{L}^{-1}$ de $\mathrm{N}$ e $183 \mathrm{mg} \mathrm{L}^{-1}$ de $\mathrm{K}$ na solução nutritiva, verificou uma produção de MS por planta, de 10,5 g e 15,7 g para as cultivares Marisa e Verônica, respectivamente. Costa et al. (1997) também encontraram resultados de MS da planta inteira maiores que os deste experimento para a cultivar Marisa e similares para a cultivar Vera $(6,73 \mathrm{~g})$. As diferenças dos resultados desses autores em relação aos deste experimento, poderiam ser devidos aos seguintes fatores: cultivares diferentes, duração do experimento, volume de solução nutritiva utilizada por planta e época do ano. 


\subsection{Concentração de nitrato na parte aérea}

A concentração de nitrato na parte aérea (Tabela 6), não apresentou interação entre as doses de nitrogênio e de potássio e as cultivares de alface. Pacheco (1996) sugeriu que esse comportamento, onde em condição de alta disponibilidade de nitrogênio, as plantas não aumentaram a absorção de nitrogênio em função da dose aplicada de forma linear, indicando haver um mecanismo eficiente de regulação da sua absorção e incorporação.

Foi constatada diferença significativa entre as cultivares somente na dose conjunta de $240 \mathrm{mg} \mathrm{L}^{-1}$ de $\mathrm{N}$ e $220 \mathrm{mg} \mathrm{L}^{-1}$ de $\mathrm{K}$ na solução nutritiva.

Tabela 6 - Concentração de nitrato no MS da parte aérea de duas cultivares de alface (Marisa e Vera). Média de três repetições.

\begin{tabular}{ccccc}
\hline & Tratamento & \multicolumn{2}{c}{ Nitrato } \\
\cline { 4 - 5 } $\mathrm{N}$ & & $\mathrm{K}$ & \multicolumn{2}{c}{$\left(\mathrm{mg} \mathrm{kg}^{-1}\right)$} \\
\hline & $\left(\mathrm{mg} \mathrm{L}^{-1}\right)$ & & Marisa & Vera \\
\hline 220 & & 160 & $5894,7 \mathrm{a}$ & $6770,2 \mathrm{a}$ \\
240 & 220 & $6244,9 \mathrm{a}$ & $8993,8 \mathrm{~b}$ \\
260 & 280 & $8608,6 \mathrm{a}$ & $6974,4 \mathrm{a}$ \\
280 & 340 & $7353,8 \mathrm{a}$ & $8521,1 \mathrm{a}$ \\
\hline
\end{tabular}

- Médias seguidas pela mesma letra, dentro de cada dose, não diferem estatisticamente entre si (teste " $t$ " $\mathrm{P}<0,05)$. $\mathrm{CV}=13,12 \%$.

Os valores de nitrato na parte aérea, encontrados neste experimento, são muito inferiores aos níveis máximos permitidos em alguns países da Europa, como na Holanda, que permite valores de até $4.500 \mathrm{mg} \mathrm{kg}^{-1}$ de MF (Boon, et al. 1990; Steingröver, et al. 1993). Segundo Pacheco (1996), esse limite europeu em 1995 foi reduzido para $3.500 \mathrm{mg} \mathrm{kg}^{-1} \mathrm{de} \mathrm{MF}$. 
Dos tratamentos estudados, a dose conjunta de $240 \mathrm{mg} \mathrm{L}^{-1}$ de $\mathrm{N}$ e de $220 \mathrm{mg} \mathrm{L}^{-1}$ de $\mathrm{K}$ na solução para a cultivar Vera foi a que apresentou o maior concentração de nitrato nos tecidos da parte aérea, $8.993,8 \mathrm{mg} \mathrm{kg}^{-1}$ de MS. Esse resultado é superior aos resultados encontrados por Costa et al. (1997) para a cultivar Babá $(8.300$ mg kg-1 de MS) e inferior aos resultados de Faquin et al. (1994) para a cultivar Elisa (17.000 mg kg-1 de MS). A diferença significativa encontrada entre os cultivares testados poderia ser explicado por cultivares diferentes poderem acumular nitrato de maneira diferente, em função da variabilidade genética (Pacheco, 1996).

Faquin et al. (1996) encontraram a quantidade de nitrato para a cultivar Verônica de 436,9 $\mathrm{mg} \mathrm{kg}^{-1}$ de MF. Braga \& Abboud (1997) encontraram quantidades de $\mathrm{NO}_{3}^{-}$acima das quantidades de ingestão diária aceitável (3,6 $\mathrm{mg} \mathrm{kg}^{-1}$ de peso vivo) para a cultivar de alface Verônica, cultivada em solo. Pacheco (1996), em repolho, encontrou valores de nitrato de 1.367 e $1.325 \mathrm{mg} \mathrm{kg}^{-1}$ de MF para as doses de 420 e $220 \mathrm{mg} \mathrm{kg}^{-1}$ de $\mathrm{N}$ aplicado no solo, respectivamente, estando esses resultados acima do limite máximo permitido pela Suíça $\left(875 \mathrm{mg} \mathrm{kg}^{-1}\right.$ no $\mathrm{MF}$ ) e abaixo do permitido pela Áustria (1.500 $\mathrm{mg} \mathrm{kg}^{-1}$ no MF).

Boon et al. (1990), na Holanda, encontraram quantidades de nitrato em alface iguais a 5.053 e $3.564 \mathrm{mg} \mathrm{kg}^{-1}$ no MF, para as épocas de dezembro e março, respectivamente. Isso comprova que a intensidade luminosa durante o ano, influencia o acúmulo de nitrato em plantas, pois em intensidade luminosa baixa ocorreu um acúmulo maior de $\mathrm{NO}_{3}{ }^{-}$ no tecido e em intensidade alta ocorreu acúmulo menor (Maynard et al. 1976; Boon et al. 1988). Esse acúmulo parece ser devido ao transporte do nitrato do local de armazenamento (o vacúolo) para o centro de atividade metabólica, que é mediado pela luz (Hopkins, 1995), e que comanda a reação de redução do nitrato (Steingröver, et al. 1993). 
Segundo Boon et al. (1990), os aumentos na intensidade luminosa causam uma diminuição na quantidade de nitrato no tecido. Por outro lado há um aumento na concentração de ácidos orgânicos (como o malato) e de açúcares (principalmente a glicose).

A presença do ion $\mathrm{NH}_{4}{ }^{+}$nas soluções nutritivas faz com que a quantidade de nitrato absorvida pela planta seja menor (Faquin et al. 1994; Boon et al. 1988), já que esta forma é absorvida preferencialmente pelas plantas. A redução na concentração de nitrato de 4.112 para $3.427 \mathrm{mg} \mathrm{kg}^{-1}$ no MF foi possivel com a utilização de $200 \mathrm{~g} \mathrm{~kg}^{-1}$ do ion $\mathrm{NH}_{4}{ }^{+}$na composição da solução nutritiva (Boon et al. 1988).

Kanaan \& Economakis (1993) encontraram plantas mais pesadas e com menor quantidade acumulada de $\mathrm{NO}_{3}^{-}$no tecido, quando elas foram cultivadas sob condições de temperaturas maiores do ar e da solução nutritiva e com maior disponibilidade de luz.

A concentração máxima de nitrato estimada no MF (com 961,2 g $\mathrm{kg}^{-1}$ de umidade) foi de $34,5 \mathrm{mg} \mathrm{kg}^{-1}$ para a dose $240 \mathrm{mg} \mathrm{L}^{-1}$ de $\mathrm{N}$ e, consequentemente, essas concentrações de nitrato no MS (Tabela 6) são muito inferiores às quantidades máximas permitidas na Europa. Esses valores devem ser devidos, provavelmente, à alta luminosidade que ocorreu durante o periodo experimental e às altas temperaturas do ar na casa-de-vegetação. 


\subsection{Concentração e absorção de nutrientes}

\subsubsection{Nitrogênio}

As concentrações de nitrogênio na parte aérea, nas raizes e na planta inteira, são apresentados na Tabela 7 . Não houve interação entre as doses de nitrogênio e de potássio e as cultivares de alface estudadas. Do mesmo modo, não houve diferença significativa $(\mathrm{P}<0,05)$, entre as cultivares, quanto à concentração de nitrogênio na parte aérea, nas raizes e na planta inteira.

Os resultados da quantidade de nitrogênio absorvido pela parte aérea, pelas raizes e pela planta inteira apresentaram diferença significativa entre as cultivares nos tratamentos cujas doses conjuntas de nitrogênio e potássio foram: 240 e 220; 260 e 280 (mg L-1), respectivamente. Em relação à planta inteira, o sistema radicular contribui com uma quantidade de nitrogênio muito pequena em relação à parte aérea. Isso provavelmente seja devido à grande mobilidade do nitrogênio para a parte aérea e/ou a maior participação em massa da parte aérea em relação às raízes (Tabela 7).

Nos tratamentos estudados, os resultados de concentração de nitrogênio na parte aérea, foram inferiores aos de Faquin et al. (1996) e Costa et al. (1997) que encontraram $45 \mathrm{~g} \mathrm{~kg}^{-1}$ e $60,4 \mathrm{~g} \mathrm{~kg}^{-1}$ para as cultivares Verônica e Babá, respectivamente. Por outro lado, os resultados de concentração de nitrogênio na planta inteira foram maiores que os encontrados por Koefender (1996), que obteve $36,4 \mathrm{~g} \mathrm{~kg}^{-1}$ para a cultivar Verônica. 
Tabela 7 - Concentração de nitrogênio no material seco e quantidade de nitrogênio absorvido (por planta), pela parte aérea, pelas raízes e pela planta inteira de duas cultivares de alface (Marisa e Vera) em função das doses conjuntas de nitrogênio e potássio nas soluções nutritivas. Média de três repetições.

\begin{tabular}{|c|c|c|c|c|c|c|c|}
\hline \multicolumn{2}{|c|}{ Tratamento } & \multicolumn{6}{|c|}{ Concentração de nitrogênio $\left(\mathrm{g} \mathrm{kg}^{-1}\right)$} \\
\hline $\mathrm{N}$ & $\underline{\mathrm{K}}$ & \multicolumn{2}{|c|}{ Parte aérea } & \multicolumn{2}{|c|}{ Raizes } & \multicolumn{2}{|c|}{ Planta inteira } \\
\hline \multicolumn{2}{|c|}{$\left(\mathrm{mg} \mathrm{L}^{-1}\right)$} & Marisa & Vera & Marisa & Vera & Marisa & Vera \\
\hline 220 & 160 & 36,40 & 36,63 & 35,89 & 37,59 & 36,37 & 36,66 \\
\hline 240 & 220 & 36,40 & 33,79 & 37,99 & 35,00 & 36,45 & 33,82 \\
\hline 260 & 280 & 38,55 & 36,96 & 36,82 & 38,45 & 38,51 & 37,06 \\
\hline \multirow[t]{2}{*}{280} & 340 & 34,67 & 36,03 & 37,75 & 34,93 & 34,83 & 35,99 \\
\hline & & \multicolumn{6}{|c|}{ Quantidade de nitrogênio absorvido (mg) } \\
\hline 220 & 160 & $202,7 \mathrm{a}$ & $174,3 \mathrm{a}$ & $6,8 a$ & $3,8 \mathrm{a}$ & $209,5 \mathrm{a}$ & $178,1 \mathrm{a}$ \\
\hline 240 & 220 & $214,1 \mathrm{a}$ & $177,2 \mathrm{~b}$ & $8,2 \mathrm{a}$ & $4,4 \mathrm{~b}$ & $222,3 \mathrm{a}$ & $181,6 \mathrm{~b}$ \\
\hline 260 & 280 & 237,5 a & $280,3 \mathrm{~b}$ & $7,4 \mathrm{a}$ & $17,3 \mathrm{~b}$ & $244,9 \mathrm{a}$ & $297,6 \mathrm{~b}$ \\
\hline 280 & 340 & $236,7 \mathrm{a}$ & $211,7 \mathrm{a}$ & $14,1 \mathrm{a}$ & $6,2 \mathrm{~b}$ & $250,8 \mathrm{a}$ & $217,9 \mathrm{a}$ \\
\hline
\end{tabular}

As quantidades de nitrogênio absorvidas pela parte aérea e pela planta inteira, tiveram aumentos significativos $(\mathrm{P}<0,05)$, em função do aumento nas doses de nitrogênio e de potássio nas soluções nutritivas. As equações do desdobramento das interações entre cultivares e doses de nitrogênio e de potássio são apresentadas na Figura 9. Os resultados ajustaram-se a um modelo linear para a cultivar Marisa e a um modelo quadrático para a cultivar Vera. 

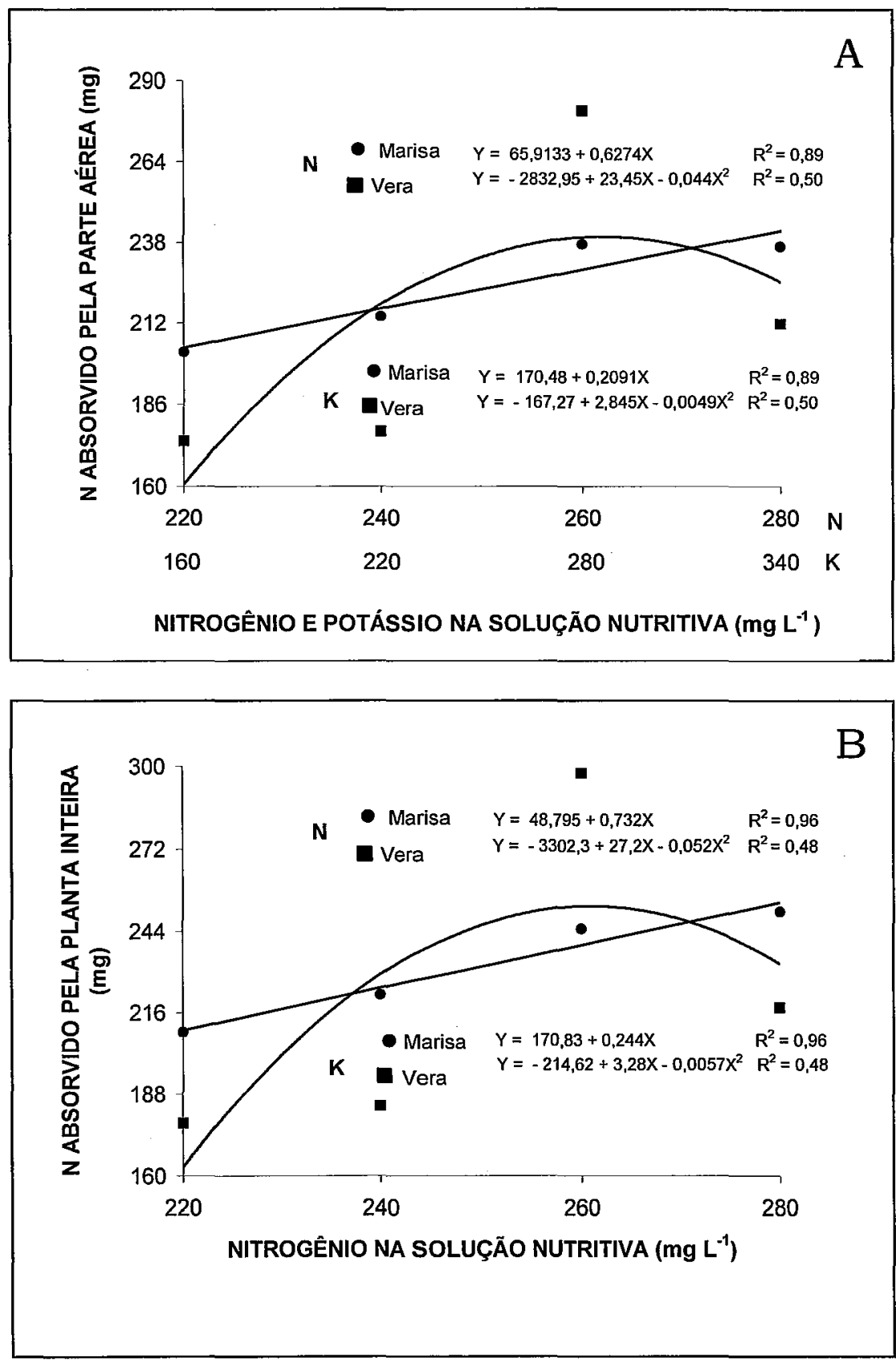

FIGURA 9 - Quantidade de nitrogênio absorvido (por planta), pela parte aérea (A) e planta inteira (B) no material seco de duas cultivares de alface (Marisa e Vera) em função das doses conjuntas de nitrogênio e potássio nas soluções nutritivas. Média de três repetições.

Houve um aumento na quantidade de nitrogênio absorvida, em função das doses de nitrogênio e de potássio na solução nutritiva. $\mathrm{Na}$ parte aérea, a amplitude dos valores foi de 174,3 e de $280,3 \mathrm{mg}$ para a 
cultivar Vera (Figura 9A). O ponto de absorção máxima de nitrogênio pela parte aérea de 239,8 $\mathrm{mg}$ foi atingido com a dose estimada de 286,1 mg $\mathrm{L}^{-1}$ de $\mathrm{K}$ nas soluções nutritivas. Para a cultivar Marisa, a quantidade de nitrogênio absorvida apresentou uma resposta linear, dentro do limite das concentrações de potássio utilizadas na solução nutritiva. Esses valores são menores em relação aos encontrados por Costa et al. (1997), que obtiveram uma quantidade de nitrogênio absorvido de $366,0 \mathrm{mg}$ na parte aérea.

Para as doses de nitrogênio utilizadas em solução nutritiva, ocorreu o mesmo comportamento em relação ao potássio (Figura 9A), sendo que para a cultivar Vera o ponto de absorção máxima de nitrogênio ocorreu com a dose estimada de $262,0 \mathrm{mg} \mathrm{L}^{-1}$ de $\mathrm{N}$.

Do mesmo modo que para as concentrações de potássio nas soluções nutritiva, a cultivar Marisa apresentou uma resposta linear às doses de nitrogênio utilizadas.

Para a dose estimada de $261,3 \mathrm{mg} \mathrm{L}^{-1}$ de $\mathrm{N}$, obteve-se a absorção máxima de nitrogênio pela planta inteira de $251,5 \mathrm{mg}$ de $\mathrm{N}$ na cultivar Vera (Figura 9B). Para potássio na solução nutritiva a dose estimada de $283,9 \mathrm{mg} \mathrm{L}^{-1}$ proporcionou a absorção máxima de nitrogênio (Figura 9B).

Furlani (1997), utilizando $195 \mathrm{mg} \mathrm{L}^{-1}$ de $\mathrm{N}$ na solução nutritiva, obteve uma quantidade de nitrogênio absorvido de $387 \mathrm{mg}$ e $588 \mathrm{mg}$ na planta inteira para as cultivares Marisa e Verônica, respectivamente, sendo, portanto, superiores aos resultados encontrados neste experimento.

Por outro lado, resultados semelhantes aos constatados neste trabalho foram encontrados por Faquin et al. (1996), que obtiveram 257,5 mg de $\mathrm{N}$ absorvido pela parte aérea, para a cultivar Verônica, 20 dias após o transplante. 


\subsubsection{Potássio}

Os valores de concentração de potássio no material seco da parte aérea diferiram significativamente somente na dose conjunta de 220 e $160 \mathrm{mg} \mathrm{L}^{-1}$ de $\mathrm{N}$ e $\mathrm{K}$, respectivamente. Para as raízes e para a planta inteira, os valores de concentração de potássio no material seco diferiram significativamente entre as duas cultivares nos tratamentos cujas doses de nitrogênio e de potássio foram (mg L-1): 220 e 160; 240 e 220; 260 e 280, respectivamente.

Para resultados de quantidade de potássio absorvido pela parte aérea, pelas raízes e pela planta inteira, encontrou-se diferença estatística entre as duas cultivares, nos tratamentos cujas doses de nitrogênio e de potássio foram: 260 e 280; 280 e 340 (mg L $\mathrm{L}^{-1}$ ), respectivamente (Tabela 8 ).

Os resultados da concentração de potássio nos tecidos da parte áerea foram maiores que os encontrados por Koefender (1996), que obteve $71,14 \mathrm{~g} \mathrm{~kg}^{-1}$ no tratamento mais produtivo, utilizando a cultivar Verônica. Entretanto, Faquin et al. (1996) encontraram concentrações inferiores (54 $\left.\mathrm{g} \mathrm{kg}^{-1}\right)$ aos desse experimento.

Costa et al. (1997) encontraram concentrações maiores $(82,9 \mathrm{~g}$ $\mathrm{kg}^{-1}$ ) na parte aérea para a cultivar de alface Babá. 
Tabela 8 - Concentração de potássio no material seco e quantidade de potássio absorvido (por planta), pela parte aérea, pelas raizes e pela planta inteira de duas cultivares de alface (Marisa e Vera) em função das doses conjuntas de nitrogênio e potássio nas soluçōes nutritivas. Média de três repetições.

\begin{tabular}{|c|c|c|c|c|c|c|c|}
\hline \multicolumn{2}{|c|}{ Tratamento } & \multicolumn{6}{|c|}{ Concentração de potássio $\left(\mathrm{g} \mathrm{kg}^{-1}\right)$} \\
\hline $\mathrm{N}$ & $\mathrm{K}$ & \multicolumn{2}{|c|}{ Parte aérea } & \multicolumn{2}{|c|}{ Raizes } & \multicolumn{2}{|c|}{ Planta inteira } \\
\hline \multicolumn{2}{|c|}{$\left(\mathrm{mg} \mathrm{L} \mathrm{L}^{-1}\right)$} & Marisa & Vera & Marisa & Vera & Marisa & Vera \\
\hline 220 & 160 & $53,5 \mathrm{a}$ & $67,8 \mathrm{~b}$ & $15,81 \mathrm{a}$ & $18,36 \mathrm{~b}$ & $52,12 \mathrm{a}$ & $66,70 \mathrm{~b}$ \\
\hline 240 & 220 & $66,3 \mathrm{a}$ & $74,1 \mathrm{a}$ & $20,91 \mathrm{a}$ & $35,70 \mathrm{~b}$ & $64,89 a$ & $78,13 \mathrm{~b}$ \\
\hline 260 & 280 & $81,4 \mathrm{a}$ & $75,0 \mathrm{a}$ & $37,23 \mathrm{a}$ & $29,07 \mathrm{~b}$ & $80,19 a$ & $72,41 \mathrm{~b}$ \\
\hline \multirow[t]{2}{*}{280} & 340 & $81,6 \mathrm{a}$ & $78,0 \mathrm{a}$ & $52,02 \mathrm{a}$ & $54,06 \mathrm{a}$ & $80,06 a$ & $77,34 \mathrm{a}$ \\
\hline & & \multicolumn{6}{|c|}{ Quantidade de potássio absorvido (mg) } \\
\hline 220 & 160 & 296,6 a & 322,9 a & $2,4 \mathrm{a}$ & $1,2 \mathrm{a}$ & $299,0 \mathrm{a}$ & $324,1 \mathrm{a}$ \\
\hline 240 & 220 & $388,3 \mathrm{a}$ & $413,9 \mathrm{a}$ & $5,4 \mathrm{a}$ & $5,0 \mathrm{a}$ & $393,7 \mathrm{a}$ & $418,9 \mathrm{a}$ \\
\hline 260 & 280 & 499,9 a & $569,2 \mathrm{~b}$ & 8,7 a & $12,9 \mathrm{~b}$ & $508,6 \mathrm{a}$ & $582,1 \mathrm{~b}$ \\
\hline 280 & 340 & $557,2 \mathrm{a}$ & $458,3 \mathrm{~b}$ & $19,2 \mathrm{a}$ & $9,7 \mathrm{~b}$ & $576,4 \mathrm{a}$ & $468,0 \mathrm{~b}$ \\
\hline
\end{tabular}

As concentrações encontradas na parte aérea e na planta inteira estão dentro da faixa de concentração considerada como adequada para a cultura (Reuter \& Robinson, 1997)

As concentrações de potássio na parte aérea e na planta inteira tiveram aumentos significativos $(\mathrm{P}<0,05)$ em função das doses de nitrogênio e de potássio nas soluções nutritivas. As equações do desdobramento das interações entre cultivares e doses conjuntas de nitrogênio e potássio são apresentadas na Figura 10. 

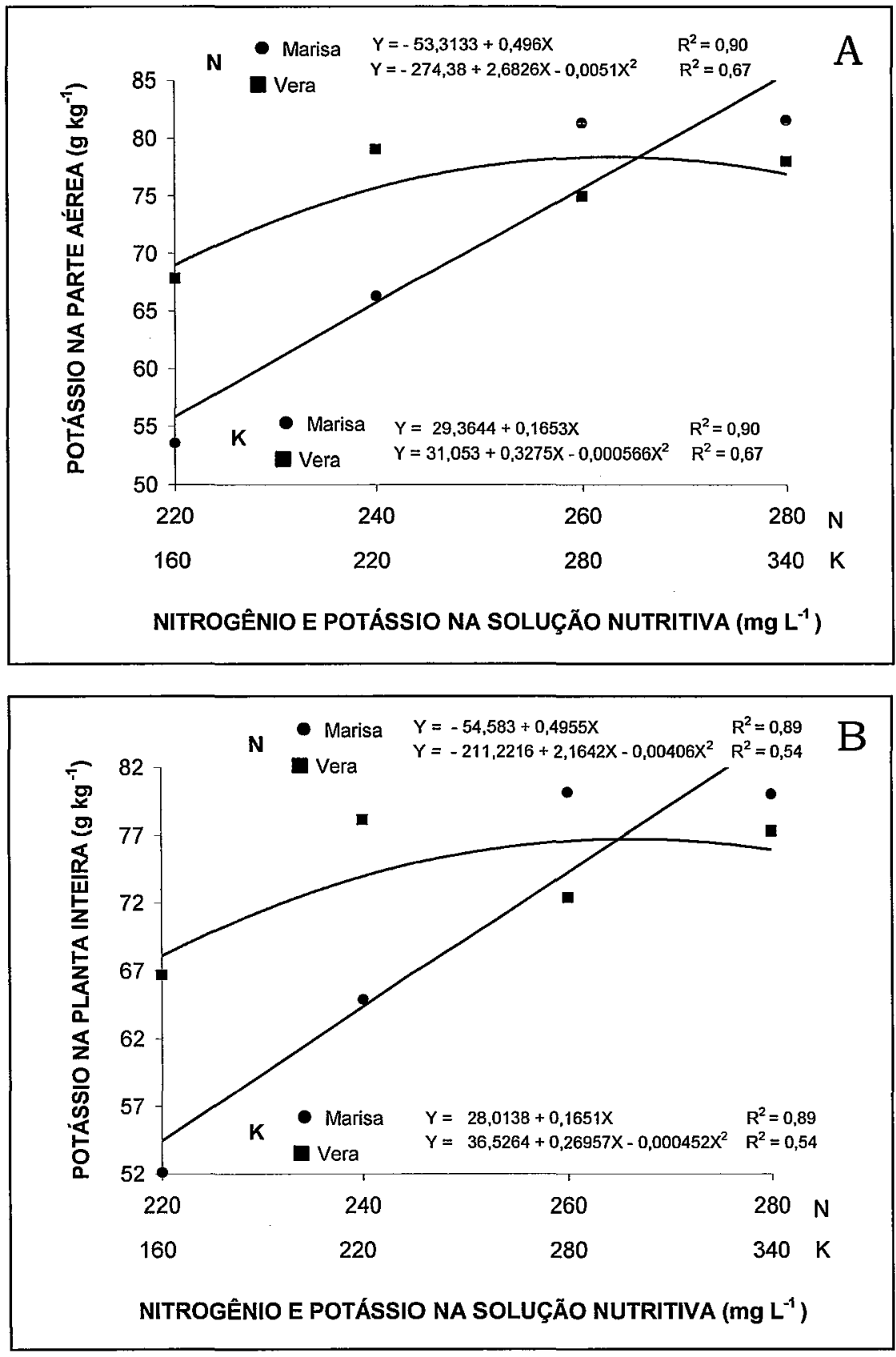

FIGURA 10 - Concentração de potássio na parte aérea (A) e planta inteira (B) (por cinco plantas) de duas cultivares de alface (Marisa e Vera) em função das doses conjuntas de nitrogênio e potássio nas soluções nutritivas. Média de três repetições.

A cultivar Vera apresentou uma resposta quadrática, quando se considerou nitrogênio e potássio nas soluções nutritivas e potássio na 
parte aérea (Figura 10A). Por outro lado, a cultivar Marisa apresentou uma resposta linear em função das doses de nitrogênio e de potássio em solução e potássio na parte aérea. Para a cultivar Vera, a concentração máxima de potássio na parte aérea foi de $78,42 \mathrm{~g} \mathrm{~kg}^{-1}$ nas doses conjuntas de $263,0 \mathrm{mg} \mathrm{L}^{-1}$ de $\mathrm{N}$ e de $289,0 \mathrm{mg} \mathrm{L}^{-1}$ de $\mathrm{K}$ na solução nutritiva.

Quanto à concentração de potássio na planta inteira (Figura 10B) em função das doses de nitrogênio e de potássio nas soluções nutritivas, a resposta das duas cultivares apresentaram a mesma tendência verificada para potássio na parte aérea, ou seja: quadrática para a cultivar Vera e linear para a cultivar Marisa. A concentração máxima de potássio na planta inteira da cultivar Vera foi de $76,9 \mathrm{~g} \mathrm{~kg}^{-1}$ nas doses conjuntas de $266,5 \mathrm{mg} \mathrm{L}^{-1}$ de $\mathrm{N}$ e de $298,2 \mathrm{mg} \mathrm{L}^{-1}$ de $\mathrm{K}$ na solução nutritiva.

Não foi possivel estabelecer-se uma concentração máxima de potássio na parte aérea e na planta inteira para a cultivar Marisa tendo em vista, que nas doses de nitrogênio e potássio utilizadas nas soluções nutritivas, o modelo de resposta seguiu um comportamento linear.

As quantidades de potássio absorvidas pela parte aérea e pela planta inteira tiveram aumentos significativos $(P<0,05)$ em função das doses de nitrogênio e de potássio nas soluções nutritivas.

As equações do desdobramento das interações entre cultivares e doses de nitrogênio e de potássio são apresentadas na Figura 11. 



FIGURA 11 - Quantidade de potássio absorvido (por planta), pela parte aérea (A) e pela planta inteira (B) no material seco de duas cultivares de alface (Marisa e Vera) em função das doses conjuntas de nitrogênio e potássio nas soluções nutritivas. Média de três repetições.

A cultivar Vera apresentou uma resposta quadrática, quando se considerou nitrogênio e potássio nas soluções nutritivas e a quantidade 
de potássio absorvido pela parte aérea (Figura 11A). O ponto de absorção máxima de potássio pela parte aérea da cultivar Vera de 519,8 $\mathrm{mg}$, foi atingido com a dose conjunta de $261,1 \mathrm{mg} \mathrm{kg}^{-1}$ de $\mathrm{N}$ e de 283,4 $\mathrm{mg} \mathrm{kg}{ }^{-1}$ de $\mathrm{K}$ na solução nutritiva, respectivamente (Figura 11A).

Na Figura 11B são apresentados os resultados para a planta inteira. A cultivar Vera apresentou a mesma tendência verificada para a parte aérea, com resposta quadrática. Encontrou-se uma quantidade máxima de absorção de potássio de $530,5 \mathrm{mg}$ de $\mathrm{K}$ com a dose conjunta estimada de $262,6 \mathrm{mg} \mathrm{kg}^{-1}$ de $\mathrm{N}$ e de $284,2 \mathrm{mg} \mathrm{kg}^{-1}$ de $\mathrm{K}$, para a cultivar Vera.

Por outro lado, a cultivar Marisa apresentou uma resposta linear em função das doses conjuntas de nitrogênio e potássio em solução e quantidade de potássio absorvido pela parte aérea e pela planta inteira. Por isso, não foi possivel estabelecer-se uma quantidade máxima de potássio absorvido pela parte aérea e pela planta inteira.

As quantidades de $\mathrm{K}$ absorvidas encontradas neste experimento, na planta inteira, são menores que os valores encontrados por Furlani (1997) que obteve 869 e $1105 \mathrm{mg}$ de K para as cultivares Marisa e Verônica, respectivamente.

\subsubsection{Fósforo}

As concentrações de fósforo na parte aérea e na planta inteira não apresentaram interação significativa entre tratamentos e cultivares.

Da mesma forma, não houve diferença significativa entre cultivares para a concentração de fósforo na parte aérea, nas raízes e na planta inteira (Tabela 9).

Os valores das quantidades de fósforo absorvidas pela parte aérea e pela planta inteira, apresentaram diferenças significativas entre 
as cultivares nos tratamentos cujas doses conjuntas de nitrogênio e potássio foram de 240 e 220; 260 e 280; 280 e 340 (mg L-1), respectivamente. Para as raízes, encontrou-se diferença significativa em todas as doses conjuntas (Tabela 9).

Tabela 9 - Concentração de fósforo no material seco e quantidade de fósforo absorvido (por planta) duas cultivares de alface (Marisa e Vera) em função das doses de nitrogênio e de potássio nas soluções nutritivas. Média de três repetições.

\begin{tabular}{|c|c|c|c|c|c|c|c|}
\hline \multicolumn{2}{|c|}{ Tratamento } & \multicolumn{6}{|c|}{ Concentração de fósforo $\left(\mathrm{g} \mathrm{kg}^{-1}\right)$} \\
\hline $\mathrm{N}$ & $\mathrm{K}$ & \multicolumn{2}{|c|}{ Parte aérea } & \multicolumn{2}{|c|}{ Raízes } & \multicolumn{2}{|c|}{ Planta inteira } \\
\hline \multicolumn{2}{|c|}{ (mg L-1) } & Marisa & Vera & Marisa & Vera & Marisa & Vera \\
\hline 220 & 160 & 7,53 & 7,67 & 8,57 & 8,57 & 7,60 & 7,69 \\
\hline 240 & 220 & 8,44 & 7,85 & 7,78 & 6,33 & 8,42 & 7,84 \\
\hline 260 & 280 & 6,74 & 7,49 & 8,16 & 8,06 & 6,79 & 7,53 \\
\hline \multirow[t]{2}{*}{280} & 340 & 8,75 & 8,02 & 8,58 & 7,78 & 8,73 & 8,02 \\
\hline & & \multicolumn{6}{|c|}{ Quantidade de fósforo absorvido (mg) } \\
\hline 220 & 160 & $42,0 \mathrm{a}$ & 36,5 a & $1,8 \mathrm{a}$ & $0,9 \mathrm{~b}$ & $43,8 \mathrm{a}$ & $37,4 \mathrm{a}$ \\
\hline 240 & 220 & $49,5 \mathrm{a}$ & $41,2 \mathrm{~b}$ & $1,7 \mathrm{a}$ & $1,0 \mathrm{~b}$ & $51,2 \mathrm{a}$ & $42,2 \mathrm{~b}$ \\
\hline 260 & 280 & $41,4 \mathrm{a}$ & $56,9 \mathrm{~b}$ & $1,7 \mathrm{a}$ & $3,6 \mathrm{~b}$ & $43,1 \mathrm{a}$ & $60,5 \mathrm{~b}$ \\
\hline 280 & 340 & $59,7 \mathrm{a}$ & $47,1 \mathrm{~b}$ & $3,2 \mathrm{a}$ & $1,3 \mathrm{~b}$ & $62,9 a$ & $48,4 \mathrm{~b}$ \\
\hline
\end{tabular}

As concentrações encontradas na parte aérea e na planta inteira estão acima da faixa de concentração (4 - $6 \mathrm{~g} \mathrm{~kg}$ ) considerada como adequada para a cultura (Reuter \& Robinson, 1997). Costa et al. (1997), encontraram valores de concentração na parte aérea mais altos que estes $\left(9,3 \mathrm{~g} \mathrm{~kg}^{-1}\right)$. Os resultados de concentração encontrados nesse experimento, são semelhantes aos encontrados por Faquin et al. (1996) e Koefender (1996).

As quantidades de fósforo absorvidas pela parte aérea e pela planta inteira, tiveram aumentos significativos $(P<0,05)$, em função das 
doses de nitrogênio e de potássio nas soluções nutritivas. As equações do desdobramento das interações entre cultivares e doses de nitrogênio e de potássio são apresentadas na Figura 12. Os resultados ajustaramse a um modelo quadrático para ambas cultivares, porém com sentidos inversos: para a cultivar Vera negativo decrescente, para a cultivar Marisa positivo crescente, em função do acréscimo de nitrogênio e potássio nas soluções nutritivas.

Segundo os modelos ajustados para a cultivar Vera, a quantidade máxima de potássio absorvido pela parte aérea de $52,5 \mathrm{mg}$ foi atingida com a dose conjunta estimada de $262,9 \mathrm{mg} \mathrm{L}^{-1}$ de $\mathrm{N}$ e de $288,9 \mathrm{mg} \mathrm{L}^{-1}$ de $\mathrm{K}$ na solução nutritiva, respectivamente (Figura 12A). Para a cultivar Marisa, obteve-se aumentos na quantidade de fósforo absorvido a partir da dose conjunta de $260 \mathrm{mg} \mathrm{L}^{-1}$ de $\mathrm{N}$ e de $280 \mathrm{mg} \mathrm{L}^{-1}$ de K (Figura 12A). 

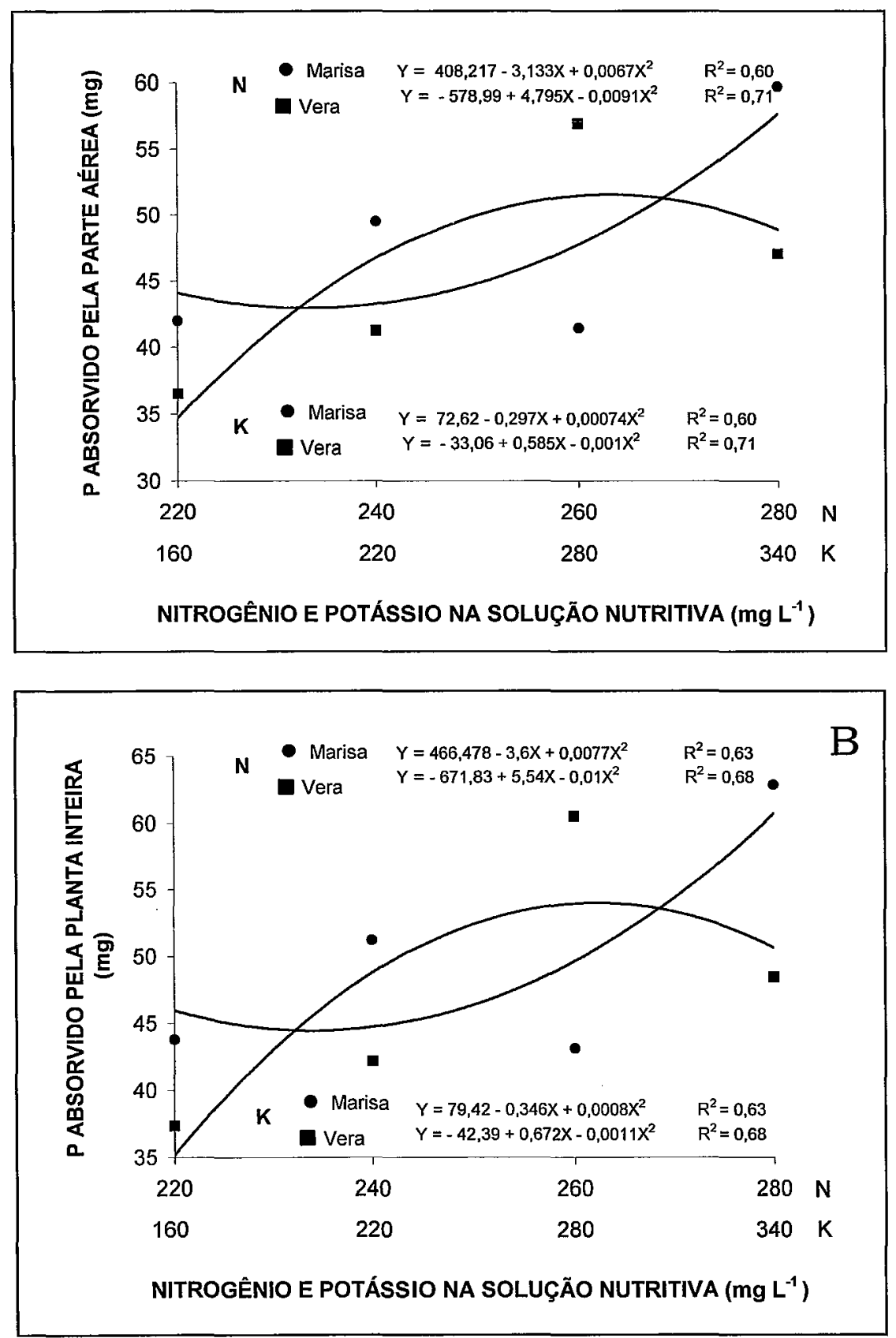

FIGURA 12 - Quantidade de fósforo absorvido (por planta), pela parte aérea (A) e pela planta inteira (B) no material seco de duas cultivares de alface (Marisa e Vera) em função das doses conjuntas de nitrogênio e potássio nas soluções nutritivas. Média de três repetições.

$\mathrm{Na}$ planta inteira, segundo os modelos ajustados para as equações, o ponto máximo de fósforo absorvido de $53,9 \mathrm{mg}$ foi atingido 
com a dose conjunta estimada de $262,2 \mathrm{mg} \mathrm{L}^{-1}$ de $\mathrm{N}$ e de $286,6 \mathrm{mg} \mathrm{L}^{-1}$ de K, respectivamente (Figura 12B).

Para a cultivar Marisa obteve-se um ponto de minima concentração de fósforo $(44,4 \mathrm{mg})$ na dose conjunta estimada de 233,8 e 202,2 $\mathrm{mg} \mathrm{L}^{-1}$ de $\mathrm{N}$ e K, respectivamente. Nas doses maiores ocorreu um aumento na quantidade de fósforo absorvida pela planta inteira (Figura 12B).

As quantidades de $\mathrm{P}$ absorvidas foram menores que as encontradas por Costa et al. (1997) e Furlani (1997).

\subsubsection{Cálcio}

As concentrações de cálcio na parte aérea e na planta inteira, tiveram aumentos significativos $(\mathrm{P}<0,05)$ em função das doses de nitrogênio e de potássio nas soluções nutritivas. As equações do desdobramento das interações entre cultivares e doses de nitrogênio e de potássio são apresentadas na Figura 13.

Devido ao coeficiente de determinação $\left(\mathrm{R}^{2}\right)$ da concentração de cálcio na parte aérea com doses de nitrogênio e potássio para a cultivar Vera serem muito menores que 0,10 , são apresentadas apenas as equações para a cultivar Marisa (Figura 13A).

Na parte aérea da cultivar Marisa, as concentrações de cálcio nos tecidos foram decrescentes até a dose conjunta estimada de $260 \mathrm{mg} \mathrm{L}^{-1}$ de $\mathrm{N}$ e $280 \mathrm{mg} \mathrm{L}^{-1}$ de $\mathrm{K}$, na qual obteve-se o ponto de concentração minima $\left(12,8 \mathrm{mg} \mathrm{kg}^{-1}\right)$. Para doses superiores de nitrogênio e de potássio, esta cultivar apresentou concentrações crescentes de cálcio no tecido (Figura 13A). 

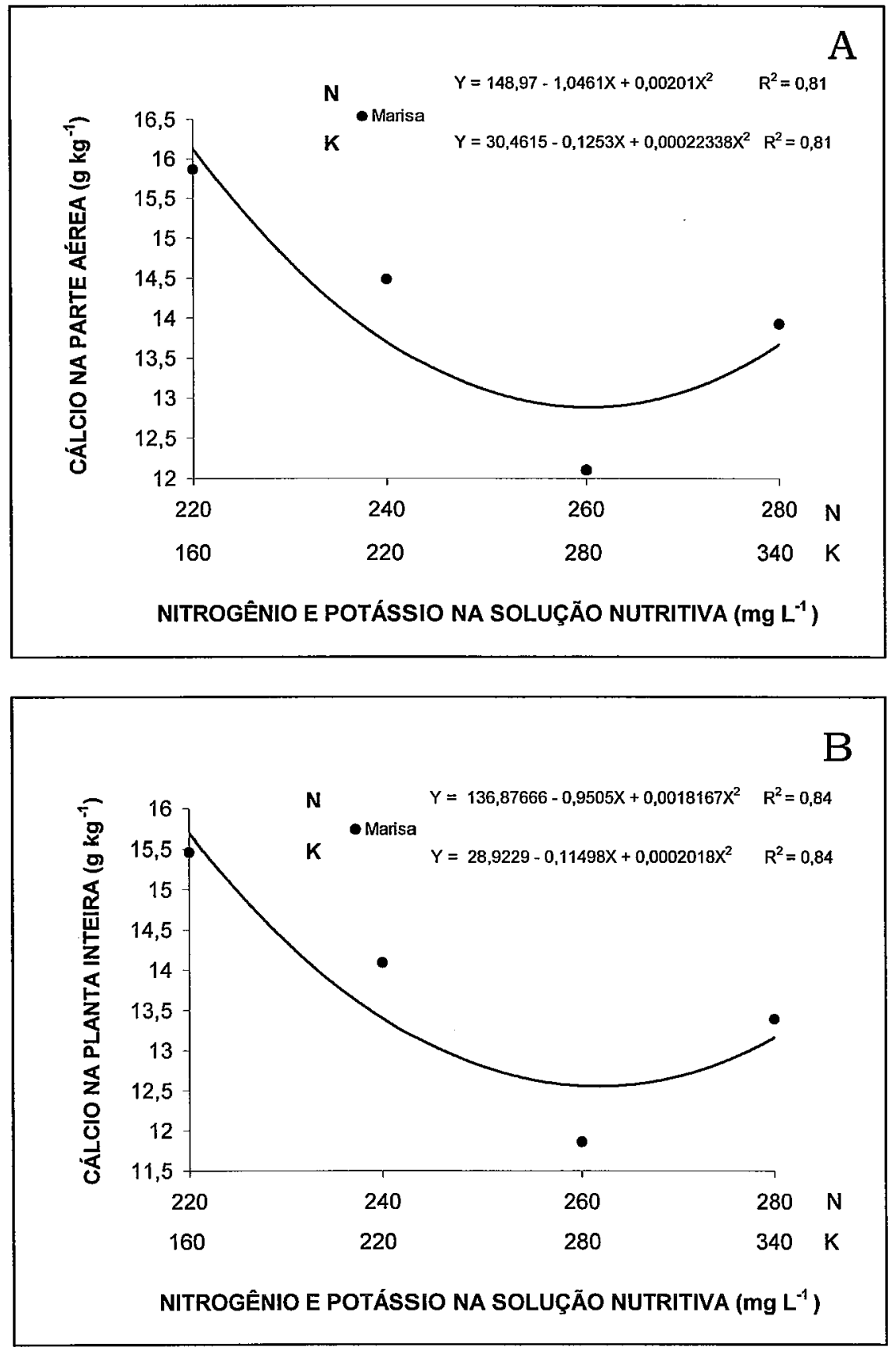

FIGURA 13 - Concentração de cálcio na parte aérea (A) e na planta inteira (B) da cultivar de alface Marisa em função das doses conjuntas de nitrogênio e potássio nas soluções nutritivas. Média de três repetições.

O resultado do ponto de mínima concentração de cálcio na parte aérea de $12,8 \mathrm{mg} \mathrm{kg}^{-1}$ foram maiores que os resultados de concentração 
encontrados por Costa et al. (1997) de 7,9 $\mathrm{g} \mathrm{kg}^{-1}$ para alface, cultivar Babá.

Os resultados foram semelhantes aos encontrados por Faquin et al. (1996) de $12,9 \mathrm{~g} \mathrm{~kg}^{-1}$, tidos como adequados para a cultura da alface em hidroponia.

Os resultados da concentração de cálcio na planta inteira ajustaram-se a um modelo quadrático para a cultivar Marisa, tanto para doses de nitrogênio, como para doses de potássio nas soluções nutritivas, respectivamente (Figura 13B).

Para a concentração de cálcio na planta inteira, ocorreu o mesmo comportamento verificado para a parte aérea. A dose conjunta estimada de $261,4 \mathrm{mg} \mathrm{L}^{-1}$ de $\mathrm{N}$ e de $284,9 \mathrm{mg} \mathrm{L}^{-1}$ de $\mathrm{K}$ proporcionou o ponto de concentração minima de cálcio nos tecidos que foi de $12,55 \mathrm{mg} \mathrm{kg} \mathrm{kg}^{-1}$ (Figura 13B). As concentrações encontradas na parte aérea estão dentro da faixa de concentração considerada como adequada por Reuter \& Robinson (1997), que indica uma faixa de 14,0 a $15 \mathrm{~g} \mathrm{~kg}^{-1}$ de cálcio.

As quantidades de cálcio absorvidas pela parte aérea e pela planta inteira, tiveram aumentos significativos $(P<0,05)$, em função das doses de nitrogênio e de potássio nas soluções nutritivas. As equações do desdobramento das interações entre cultivares e doses de nitrogênio e de potássio são apresentadas na Figura 14. 

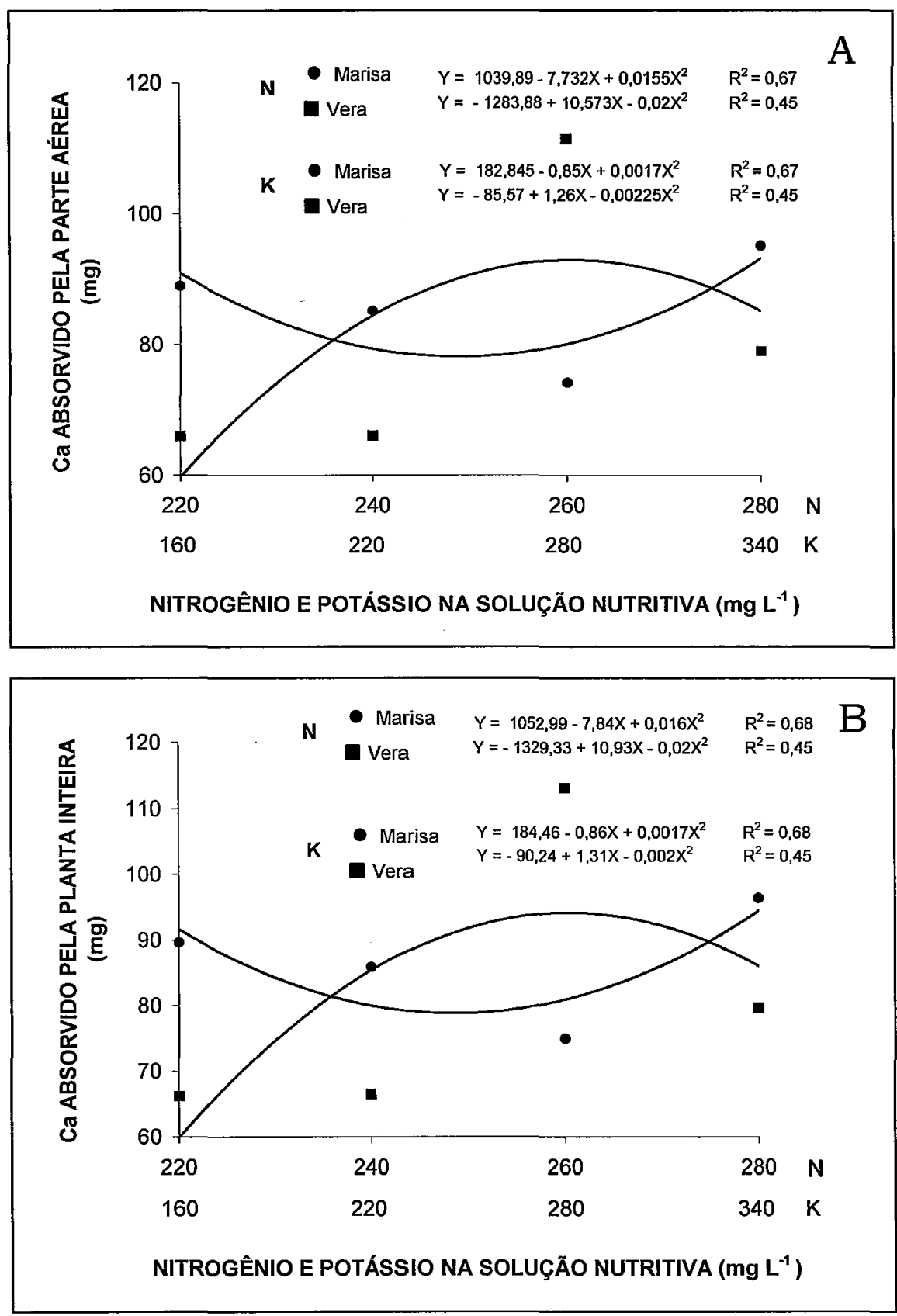

FIGURA 14 - Quantidade de cálcio absorvido (por planta), pela parte aérea (A) e pela planta inteira (B) no material seco de duas cultivares de alface (Marisa e Vera) em função das doses conjuntas de nitrogênio e potássio nas soluções nutritivas. Média de três repetições.

A cultivar Vera apresentou quantidades de cálcio absorvido que variaram entre 65,9 e $111,4 \mathrm{mg}$ na parte aérea e 66,2 e 113,0 mg na 
planta inteira. Para a cultivar Marisa a quantidade de cálcio absorvido variou entre 85,2 e $95,1 \mathrm{mg}$ na parte aérea e 85,9 e 96,4 na planta inteira.

Para a cultivar Marisa, com as doses conjuntas estimadas de 249,4 $\mathrm{mg} \mathrm{L}^{-1}$ de $\mathrm{N}$ e de $250 \mathrm{mg} \mathrm{L}^{-1}$ de $\mathrm{K}$ na solução nutritiva, obteve-se um ponto de absorção mínima na parte aérea de 76,6 mg de Ca (Figura 14A). Na planta inteira, o ponto de minima absorção de cálcio foi de 75,7 mg com a dose conjunta estimada de 245 e de $252,9 \mathrm{mg} \mathrm{L}^{-1}$ de $\mathrm{N}$ e de $\mathrm{K}$, respectivamente (Figura 14B).

Os resultados da quantidade de cálcio absorvido pela parte aérea são menores que os de Furlani (1997) que obteve 145 mg de cálcio para a cultivar Marisa e maiores que os de Costa et al. (1997), que obtiveram 47,9 mg de cálcio para a cultivar Babá.

Comparando-se as cultivares, os resultados da concentração de cálcio na parte aérea e na planta inteira apresentaram diferença significativa entre as duas cultivares nos tratamentos cujas doses conjuntas de nitrogênio e potássio foram: 220 e 160; 240 e 220; 260 e

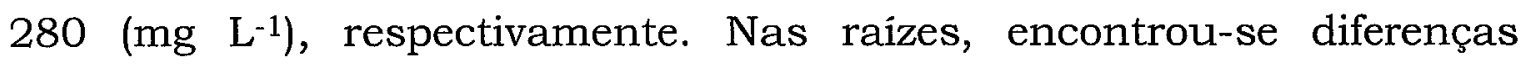
significativas nas doses conjuntas de 240 e 220, 260 e 280 e, 280 e 340 mg $\mathrm{L}^{-1}$ de $\mathrm{N}$ e de $\mathrm{K}$, respectivamente. Os resultados da quantidade de cálcio absorvido pela parte aérea e pela planta inteira apresentaram diferença estatística em todas as doses, demonstrando assim a absorção diferenciada entre as duas cultivares. Para as raizes, encontrou-se diferenças significativas nas doses conjuntas 240 e 220, 260 e $280 \mathrm{mg}$ $\mathrm{L}^{-1}$ de $\mathrm{N}$ e de $\mathrm{K}$, respectivamente (Tabela 10 ). 
Tabela 10 - Concentração de cálcio no material seco e quantidade de cálcio absorvido (por planta), pela parte aérea, pelas raízes e pela planta inteira de duas cultivares de alface (Marisa e Vera) em função das doses conjuntas de nitrogênio e potássio nas soluções nutritivas. Média de três repetições.

\begin{tabular}{|c|c|c|c|c|c|c|c|}
\hline \multicolumn{2}{|c|}{ Tratamento } & \multicolumn{6}{|c|}{ Concentração de cálcio $\left(\mathrm{g} \mathrm{kg}^{-1}\right)$} \\
\hline $\mathrm{N}$ & $\mathrm{K}$ & \multicolumn{2}{|c|}{ Parte aérea } & \multicolumn{2}{|c|}{ Raizes } & \multicolumn{2}{|c|}{ Planta inteira } \\
\hline \multicolumn{2}{|c|}{$\left(\mathrm{mg} \mathrm{L}^{-1}\right)$} & Marisa & Vera & Marisa & Vera & Marisa & Vera \\
\hline 220 & 160 & $15,9 \mathrm{a}$ & $13,8 \mathrm{~b}$ & $3,03 \mathrm{a}$ & 3,28 a & $15,46 \mathrm{a}$ & $13,61 \mathrm{~b}$ \\
\hline 240 & 220 & $14,5 \mathrm{a}$ & $12,6 \mathrm{~b}$ & $3,37 \mathrm{a}$ & $5,23 \mathrm{~b}$ & $14,09 \mathrm{a}$ & $12,42 \mathrm{~b}$ \\
\hline 260 & 280 & $12,1 \mathrm{a}$ & $14,7 \mathrm{~b}$ & $4,45 \mathrm{a}$ & $3,68 \mathrm{~b}$ & $11,86 \mathrm{a}$ & $14,08 \mathrm{~b}$ \\
\hline \multirow[t]{2}{*}{280} & 340 & $13,9 \mathrm{a}$ & $13,4 \mathrm{a}$ & $3,47 \mathrm{a}$ & $4,27 \mathrm{~b}$ & $13,39 \mathrm{a}$ & $13,16 \mathrm{a}$ \\
\hline & & \multicolumn{6}{|c|}{ Quantidade de cálcio absorvido (mg) } \\
\hline 220 & 160 & 88,9 a & $65,9 \mathrm{~b}$ & $0,7 \mathrm{a}$ & 0,3 a & 89,6 a & $66,2 \mathrm{~b}$ \\
\hline 240 & 220 & $85,2 \mathrm{a}$ & $65,9 \mathrm{~b}$ & $0,7 \mathrm{a}$ & $0,6 \mathrm{a}$ & 85,9 a & $66,5 \mathrm{~b}$ \\
\hline 260 & 280 & $74,1 \mathrm{a}$ & $111,4 \mathrm{~b}$ & $0,9 a$ & $1,6 \mathrm{~b}$ & $75,0 \mathrm{a}$ & $113,0 \mathrm{~b}$ \\
\hline 280 & 340 & $95,1 \mathrm{a}$ & $78,9 \mathrm{~b}$ & $1,3 \mathrm{a}$ & $0,8 \mathrm{~b}$ & $96,4 \mathrm{a}$ & $79,7 \mathrm{~b}$ \\
\hline
\end{tabular}

\subsubsection{Magnésio}

$\mathrm{Na}$ comparação entre as cultivares não houve diferença significativa na concentração de magnésio na parte aérea, nas raizes e na planta inteira. Para as quantidades absorvidas de magnésio pela parte aérea, pelas raízes e pela planta inteira, também não se observaram diferença significativa entre as cultivares e os tratamentos (Tabela 11).

Para as quantidades de magnésio absorvidas pela parte aérea e pela planta inteira, não se obteve interação entre as cultivares e os tratamentos. 
Tabela 11 - Concentração de magnésio no material seco e quantidade de magnésio absorvido (por planta) de duas cultivares de alface (Marisa e Vera) em função das doses conjuntas de nitrogênio e potássio nas soluções nutritivas. Média de três repetições.

\begin{tabular}{|c|c|c|c|c|c|c|c|}
\hline \multicolumn{2}{|c|}{ Tratamento } & \multicolumn{6}{|c|}{ Concentração de magnésio (g kg-1) } \\
\hline $\mathbf{N}$ & $\mathrm{K}$ & \multicolumn{2}{|c|}{ Parte aérea } & \multicolumn{2}{|c|}{ Raizes } & \multicolumn{2}{|c|}{ Planta inteira } \\
\hline \multicolumn{2}{|c|}{$\left(\mathrm{mg} \mathrm{L}^{-1}\right)$} & Marisa & Vera & Marisa & Vera & Marisa & Vera \\
\hline 220 & 160 & 3,94 & 4,14 & 2,14 & 1,69 & 3,88 & 4,10 \\
\hline 240 & 220 & 3,61 & 3,29 & 2,16 & 1,78 & 3,56 & 3,26 \\
\hline 260 & 280 & 3,37 & 3,10 & 1,86 & 2,33 & 3,33 & 3,05 \\
\hline \multirow[t]{2}{*}{280} & 340 & 2,70 & 3,18 & 1,54 & 1,16 & 2,65 & 3,12 \\
\hline & & \multicolumn{6}{|c|}{ Quantidade de magnésio absorvido (mg) } \\
\hline 220 & 160 & 22,1 & 19,7 & 0,4 & 0,2 & 22,5 & 19,9 \\
\hline 240 & 220 & 21,3 & 17,2 & 0,4 & 0,2 & 21,7 & 17,4 \\
\hline 260 & 280 & 20,9 & 23,5 & 0,4 & 1,0 & 21,3 & 24,5 \\
\hline 280 & 340 & 18,5 & 18,7 & 0,6 & 0,2 & 19,1 & 18,9 \\
\hline
\end{tabular}

- Médias seguidas pela mesma letra, dentro de cada dose, não diferem estatisticamente entre si (teste “t” $\mathrm{P}<0,05) . \mathrm{CV}=9,93 \%$ e $13,8 \%$ (concentração e quantidade, respectivamente).

As concentrações de magnésio na parte aérea e na planta inteira não apresentaram interação entre doses e cultivares, mas somente entre as doses. Por isso, equações lineares (Figura 15) representam o comportamento médio das cultivares.

As concentrações encontradas na parte aérea estão dentro da faixa de concentração considerado como adequada por Reuter \& Robinson (1997), que indica uma faixa de 3,0 a 5,0 $\mathrm{g} \mathrm{kg}^{-1}$ de magnésio.

Esse comportamento decrescente, com o aumento das doses, pode ser explicado pela inibição competitiva entre os cátions $\mathrm{K}^{+}$e $\mathrm{Mg}^{2+}$, na qual o cátion $\mathrm{K}^{+}$é absorvido preferencialmente (Marschner, 1995). 

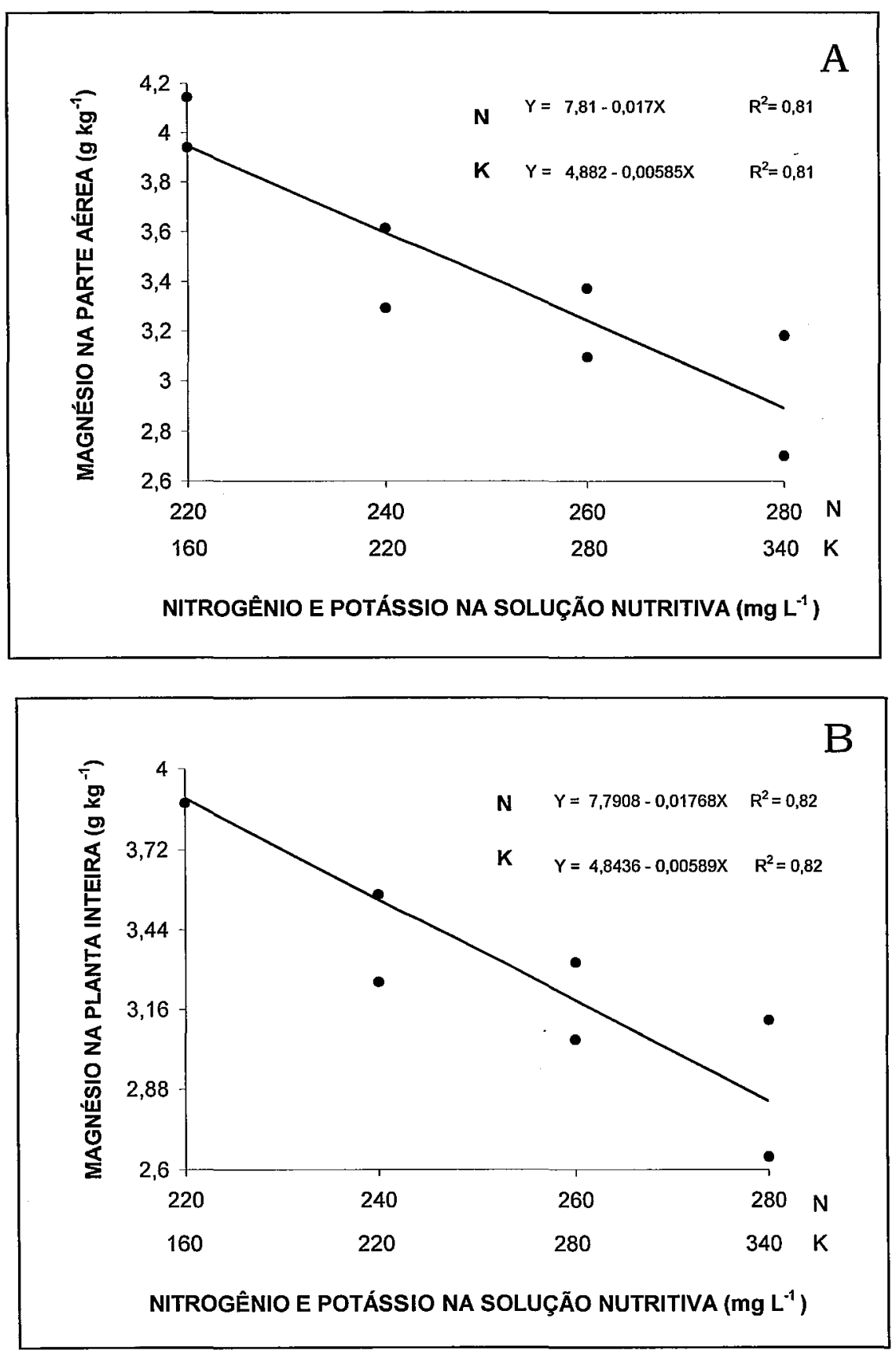

FIGURA 15 - Concentração de magnésio na parte aérea (A) e na planta inteira (B) das médias das duas cultivares de alface (Marisa e Vera) em função das doses conjuntas de nitrogênio e potássio nas soluções nutritivas. Média de três repetições. 


\subsubsection{Enxofre}

Houve diferença significativa nos valores de concentração de enxofre na parte aérea e na planta inteira entre as duas cultivares, nos tratamentos cujas doses conjuntas de nitrogênio e potássio foram: $220 \mathrm{e}$ 160; 280 e $340\left(\mathrm{mg} \mathrm{L}^{-1}\right)$, respectivamente. Para as concentrações de enxofre nas raizes observou-se diferença significativa nas doses conjuntas de 240 e 220 e de 260 e 280 mg $\mathrm{L}^{-1}$ de $\mathrm{N}$ e de K, respectivamente. Para os resultados de quantidade de enxofre absorvido pela parte aérea e pela planta inteira encontrou-se diferença estatistica apenas na dose conjunta de $280 \mathrm{mg} \mathrm{L}^{-1}$ de $\mathrm{N}$ e de $340 \mathrm{mg} \mathrm{L}^{-1}$ de K. Nas raizes encontrou-se diferenças significativas nas doses conjuntas de 260 e 280 e de 280 e $340 \mathrm{mg} \mathrm{L}^{-1}$ de $\mathrm{N}$ e de $\mathrm{K}$, respectivamente. (Tabela 12).

Tabela 12 - Concentração de enxofre no material seco e quantidade de enxofre absorvido (por planta) de duas cultivares de alface (Marisa e Vera) em função das doses conjuntas de nitrogênio e potássio nas soluções nutritivas. Média de três repetições.

\begin{tabular}{|c|c|c|c|c|c|c|c|}
\hline \multicolumn{2}{|c|}{ Tratamento } & \multicolumn{6}{|c|}{ Concentração de enxofre ( $\left.\mathrm{g} \mathrm{kg}^{-1}\right)$} \\
\hline $\mathrm{N}$ & $\mathrm{K}$ & \multicolumn{2}{|c|}{ Parte aérea } & \multicolumn{2}{|c|}{ Raizes } & \multicolumn{2}{|c|}{ Planta inteira } \\
\hline \multicolumn{2}{|c|}{$\left(\mathrm{mg} \mathrm{L}^{-1}\right)$} & Marisa & Vera & Marisa & Vera & Marisa & Vera \\
\hline 220 & 160 & $3,20 \mathrm{a}$ & $3,68 \mathrm{~b}$ & 5,79 a & $6,40 \mathrm{~b}$ & 3,31 a & $3,75 \mathrm{~b}$ \\
\hline 240 & 220 & $3,29 \mathrm{a}$ & $3,62 \mathrm{a}$ & 7,45 a & $6,86 b$ & $3,44 \mathrm{a}$ & $3,69 \mathrm{a}$ \\
\hline 260 & 280 & $3,68 \mathrm{a}$ & $3,16 \mathrm{~b}$ & $6,31 \mathrm{a}$ & $6,13 \mathrm{a}$ & 3,76 a & $3,33 \mathrm{~b}$ \\
\hline \multirow[t]{2}{*}{280} & 340 & $3,50 \mathrm{a}$ & $3,60 \mathrm{a}$ & 7,85 a & 8,37 a & $3,72 \mathrm{a}$ & $3,72 \mathrm{a}$ \\
\hline & & \multicolumn{6}{|c|}{ Quantidade de enxofre absorvido (mg) } \\
\hline 220 & 160 & $17,8 \mathrm{a}$ & $17,5 \mathrm{a}$ & $1,3 \mathrm{a}$ & $0,8 \mathrm{a}$ & $19,1 \mathrm{a}$ & $18,3 \mathrm{a}$ \\
\hline 240 & 220 & $19,3 \mathrm{a}$ & $18,8 \mathrm{a}$ & $1,7 \mathrm{a}$ & $0,9 \mathrm{a}$ & $21,0 \mathrm{a}$ & 19,7 a \\
\hline 260 & 280 & $22,7 \mathrm{a}$ & $24,0 \mathrm{a}$ & $1,2 \mathrm{a}$ & $2,8 \mathrm{~b}$ & $23,9 \mathrm{a}$ & $26,8 \mathrm{a}$ \\
\hline 280 & 340 & $23,9 \mathrm{a}$ & $21,1 \mathrm{~b}$ & $2,9 \mathrm{a}$ & $1,4 \mathrm{~b}$ & $26,8 \mathrm{a}$ & $22,5 \mathrm{~b}$ \\
\hline
\end{tabular}


As concentrações de enxofre, apresentaram aumentos significativos $(P<0,05)$ apenas para a cultivar Marisa em função das doses de nitrogênio e de potássio nas soluções nutritivas. Para a cultivar Vera, o coeficiente de determinação foi inferior a 0,10 . Portanto são apresentadas somente as equações de regressão do desdobramento das interações de nitrogênio e de potássio e enxofre na parte aérea da cultivar Marisa (Figura 16).

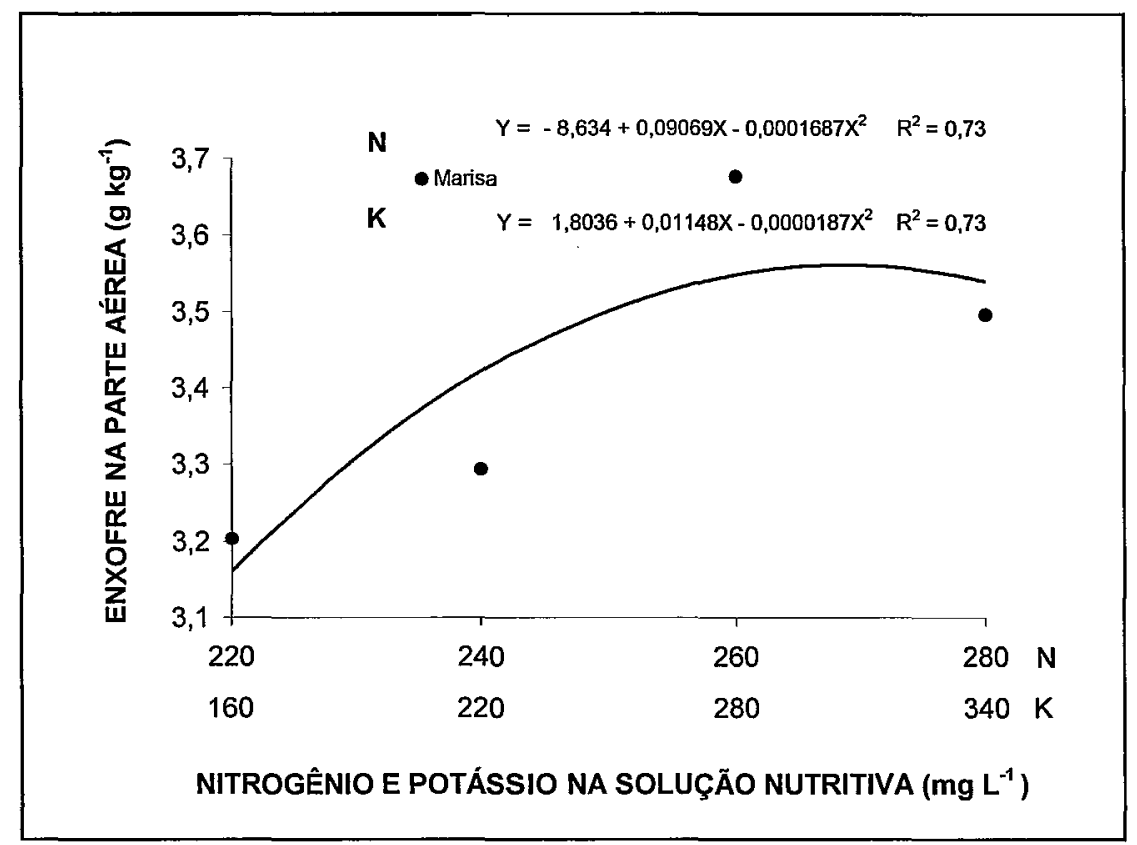

FIGURA 16 - Concentração de enxofre na parte aérea (por cinco plantas) da cultivar de alface Marisa em função das doses conjuntas de nitrogênio e potássio nas soluções nutritivas. Média de três repetições.

A concentração máxima de enxofre na parte aérea foi de $3,56 \mathrm{~g}$ $\mathrm{kg}^{-1}$, para a cultivar Marisa, com dose conjunta estimada de 306,9 mg $\mathrm{L}^{-1}$ de $\mathrm{N}$ e de $268,8 \mathrm{mg} \mathrm{L}^{-1}$ de $\mathrm{K}$ na solução nutritiva, respectivamente (Figura 16).

As concentrações de enxofre encontradas na parte aérea estão dentro da faixa de concentração considerado como adequada por Reuter \& Robinson (1997), que indica uma faixa de 3,0 a 4,0 $\mathrm{g} \mathrm{kg}^{-1}$ de enxofre. 
As quantidades de enxofre absorvidas pela parte aérea e pela planta inteira, tiveram aumentos significativos $(\mathrm{P}<0,05)$ em função das doses de nitrogênio e de potássio nas soluções nutritivas. As equações do desdobramento das interações entre cultivares e doses de nitrogênio e de potássio são apresentadas na Figura 17.

O ponto de absorção máxima de enxofre $(22,3 \mathrm{mg})$ pela parte aérea da cultivar Vera (Figura 17A) foi atingido com a dose conjunta estimada de $263,3 \mathrm{mg} \mathrm{kg}^{-1}$ de $\mathrm{N}$ e $295,8 \mathrm{mg} \mathrm{kg}^{-1}$ de $\mathrm{K}$ na solução nutritiva. Costa et al. (1997) obtiveram resultados da quantidade de enxofre absorvido pela parte aérea menores que nesse experimento $(11,5$ mg de enxofre).

A cultivar Marisa apresentou uma resposta linear quando se considerou nitrogênio e potássio na solução nutritiva e quantidade de enxofre absorvido pela parte aérea e pela planta inteira. Por apresentar este modelo de resposta, não foi possivel estabelecer-se o ponto de absorção máxima de enxofre pela parte aérea e pela planta interia.

$\mathrm{Na}$ Figura 17B, para a planta inteira, encontrou-se uma quantidade máxima de absorção de enxofre de $24,7 \mathrm{mg}$ para a dose conjunta estimada de $264 \mathrm{mg} \mathrm{kg}^{-1}$ de $\mathrm{N}$ e $291,9 \mathrm{mg} \mathrm{kg}^{-1}$ de $\mathrm{K}$.

Os resultados da quantidade de enxofre absorvido pela planta inteira são maiores que os de Faquin et al. (1996) que obtiveram 18,4 mg de enxofre para a cultivar Verônica. 

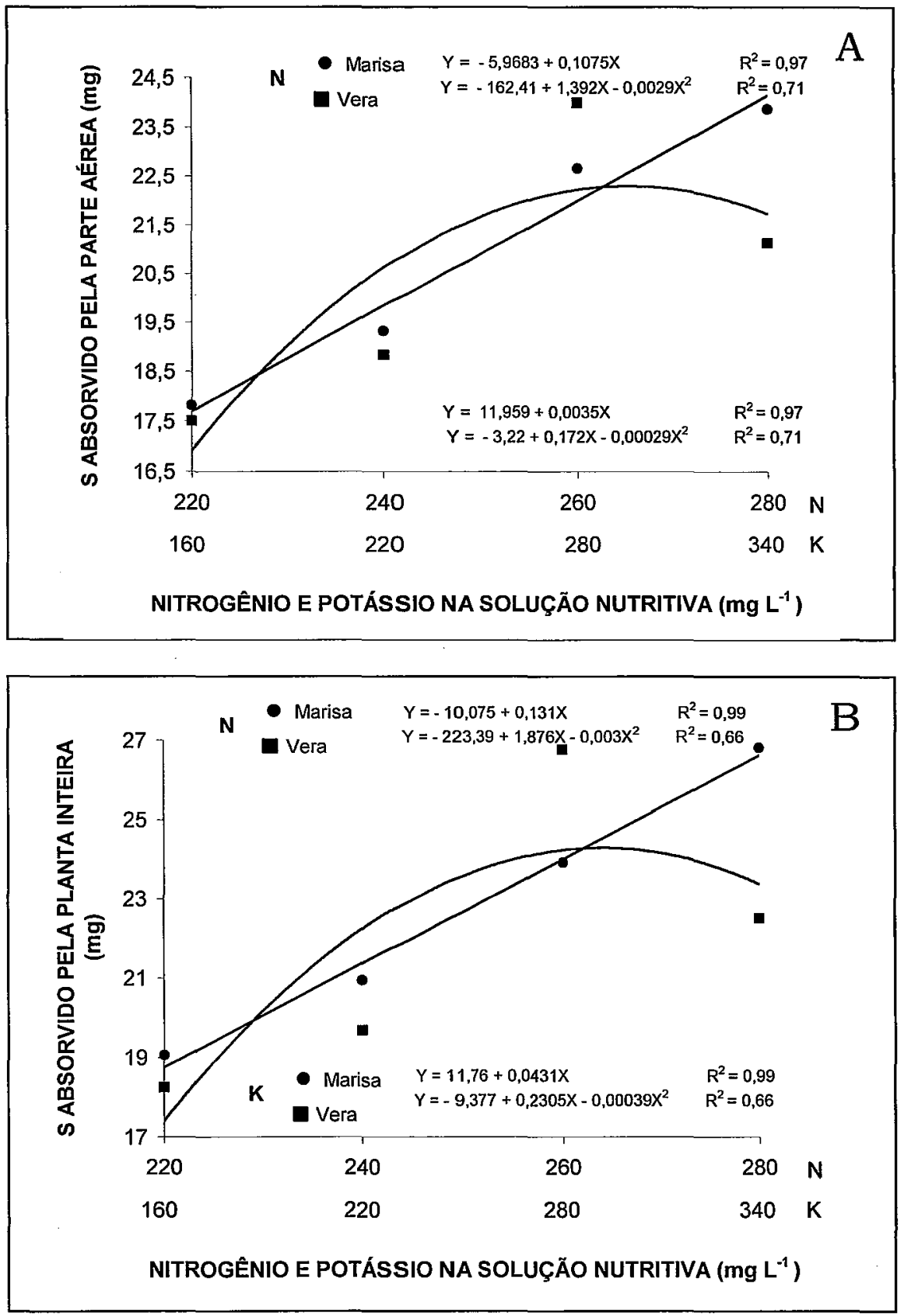

FIGURA 17 - Quantidade de enxofre absorvido (por planta), pela parte aérea (A) e pela planta inteira (B) no material seco de duas cultivares de alface (Marisa e Vera) em função das doses conjuntas de nitrogênio e potássio nas soluções nutritivas. Média de três repetições. 


\subsubsection{Considerações finais}

$\mathrm{Na}$ Tabela 13 podem ser visualizados os resultados da concentração de macronutrientes na parte aérea das duas cultivares de alface estudadas neste experimento. Malavolta et al. (1989), citam que os teores adequados dos macronutrientes ( $, \mathrm{P}, \mathrm{K}, \mathrm{Ca}, \mathrm{Mg}$ e S) em folhas recém-maduras, coletadas na época da formação da cabeça, são $\left(\mathrm{g} \mathrm{kg}^{-1}\right)$, respectivamente: $30 ; 3,5 ; 50 ; 20 ; 7,5$ e 3,5 .

Esse valores tidos como adequados variam muito de cultivar para cultivar, pois Faquin et al. (1996), estudando a cultivar Verônica de alface em hidroponia, encontrou resultados de concentrações adequada de macronutrientes na parte aérea de $\left(\mathrm{g} \mathrm{kg}^{-1}\right): 45 ; 7,6 ; 54 ; 12,9 ; 2,1 \mathrm{e}$ 3,1. Resultados semelhantes foram encontrados por Furlani (1997), também com a cultivar Verônica, $\left(\mathrm{g} \mathrm{kg}^{-1}\right): 39,1 ; 6,8 ; 65,3 ; 11,8 ; 3,3$ para $\mathrm{N}, \mathrm{P}, \mathrm{K}, \mathrm{Ca}$ e $\mathrm{Mg}$, respectivamente.

Os valores de concentrações de macronutrientes na parte aérea encontrados neste experimento, para todos os tratamentos e para as duas cultivares, são considerados adequados. 
Tabela 13 - Concentração de macronutrientes na parte aérea de duas cultivares de alface (Marisa e Vera) em função das doses conjuntas de nitrogênio e potássio nas soluções nutritivas. Média de três repetições.

\begin{tabular}{cccccccc}
\hline \multicolumn{2}{c}{ Tratamento } & \multicolumn{6}{c}{ Concentração de macronutrientes $\left(\mathrm{g} \mathrm{kg}^{-1}\right)$} \\
\hline \multicolumn{2}{c}{$\mathrm{N}$} & $\mathrm{K}$ & \multicolumn{6}{c}{ Marisa } \\
\hline \multicolumn{2}{c}{$\left(\mathrm{mg} \mathrm{L}^{-1}\right)$} & $\mathrm{N}$ & $\mathrm{P}$ & $\mathrm{K}$ & $\mathrm{Ca}$ & $\mathrm{Mg}$ & $\mathrm{S}$ \\
\hline 220 & 160 & 36,4 & 7,5 & 53,5 & 15,9 & 3,9 & 3,2 \\
240 & 220 & 36,4 & 8,4 & 66,3 & 14,5 & 3,6 & 3,3 \\
260 & 280 & 38,5 & 6,7 & 81,4 & 12,1 & 3,4 & 3,7 \\
280 & 340 & 34,7 & 8,8 & 81,6 & 13,9 & 2,7 & 3,5 \\
\hline \multicolumn{7}{c}{} \\
\hline 20 & 160 & 36,6 & 7,7 & 67,8 & 13,8 & 4,1 & 3,7 \\
240 & 220 & 33,8 & 7,9 & 79,1 & 12,6 & 3,3 & 3,6 \\
260 & 280 & 36,9 & 7,5 & 75,0 & 14,7 & 3,1 & 3,2 \\
280 & 340 & 36,0 & 8,0 & 78,0 & 13,4 & 3,2 & 3,6 \\
\hline
\end{tabular}

Na Tabela 14 observa-se a produção de material seco da parte aérea e a extração de macronutrientes pela parte aérea. Observa-se diferenças significativas na produção de material seco da parte aérea e consequentemente também nas quantidades de nutrientes extraídos pela parte aérea. Essas diferenças parece ser devido às cultivares diferentes e também à idade de colheita das plantas, refletida pela menor produção de material seco da parte aérea (Furlani, 1997).

Pode-se verificar, de um modo geral, que a extração de macronutrientes obedece à seguinte ordem decrescente: $\mathrm{K}>\mathrm{N}>\mathrm{Ca}>\mathrm{P}>\mathrm{Mg}>\mathrm{S}$. Resultados semelhantes foram relatados por Furlani (1997) e por Faquin et al. (1996), porém com a cultivar Verônica. 
Tabela 14 - Material seco e quantidade de macronutrientes absorvidos (por planta), pela parte aérea de duas cultivares de alface (Marisa e Vera) em função das doses conjuntas de nitrogênio e potássio nas soluções nutritivas. Média de três repetições.

\begin{tabular}{|c|c|c|c|c|c|c|c|c|}
\hline \multicolumn{3}{|c|}{ Tratamento } & \multicolumn{6}{|c|}{ Quantidade de macronutrientes (mg) } \\
\hline $\mathrm{N}$ & $\mathrm{K}$ & \multirow{2}{*}{$\begin{array}{c}\text { Material } \\
\text { Seco }(g)\end{array}$} & \multicolumn{6}{|c|}{ Marisa } \\
\hline \multicolumn{2}{|c|}{$\left(\mathrm{mg} \mathrm{L}^{-1}\right)$} & & $\mathrm{N}$ & $\mathrm{P}$ & $\mathrm{K}$ & $\mathrm{Ca}$ & $\mathrm{Mg}$ & $\mathrm{S}$ \\
\hline 220 & 160 & 5,56 & 202,7 & 42,0 & 296,6 & 88,9 & 22,1 & 17,8 \\
\hline 240 & 220 & 5,88 & 214,1 & 49,5 & 388,3 & 85,2 & 21,3 & 19,3 \\
\hline 260 & 280 & 6,15 & 237,5 & 41,4 & 499,9 & 74,1 & 20,9 & 22,7 \\
\hline \multirow[t]{2}{*}{280} & 340 & 6,83 & 236,7 & 59,7 & 557,2 & 95,1 & 18,5 & 23,9 \\
\hline & & & \multicolumn{6}{|c|}{ Vera } \\
\hline 220 & 160 & 4,76 & 174,3 & 36,5 & 322,9 & 65,9 & 19,7 & 17,5 \\
\hline 240 & 220 & 5,24 & 177,2 & 41,2 & 413,9 & 65,9 & 17,2 & 18,8 \\
\hline 260 & 280 & 7,59 & 280,3 & 56,9 & 569,2 & 111,4 & 23,5 & 24,0 \\
\hline 280 & 340 & 5,88 & 211,7 & 47,1 & 458,3 & 78,9 & 18,7 & 21,1 \\
\hline
\end{tabular}




\section{CONCLUSÕES}

Os resultados permitiram concluir-se que:

- para as duas cultivares de alface estudadas (Marisa e Vera), - não se observou concentrações de nitrato na parte aérea acima da dose diária aceitâvel;

- as produções de material fresco e de material seco da parte aérea e da planta inteira das duas cultivares de alface foram influenciadas pelos tratamentos, ajustando-se a modelos linear (cultivar Marisa) e quadrático (cultivar Vera);

- a cultivar Vera alcançou uma maior produção de material fresco e seco da parte aérea com uma dose conjunta de $\mathrm{N}$ e $\mathrm{K}$ menor que a cultivar Marisa.

- as concentrações de $\mathrm{K}$ e de Ca na parte aérea e na planta inteira, e de $\mathrm{S}$ na parte aérea, tiveram aumentos significativos em função das doses de $\mathrm{N}$ e de $\mathrm{K}$ nas soluções nutritivas, com interação entre doses e cultivares. $\mathrm{O} \mathrm{Mg}$ apresentou redução significativa, com interação apenas para doses;

- as quantidades de N, P, K, Ca e S absorvidas pela parte aérea e pela planta inteira tiveram aumentos significativos em função das doses conjuntas de $\mathrm{N}$ e K nas soluçōes nutritivas, com interação entre doses e cultivares; 
- a cultivar Vera teve uma melhor eficiência na utilização de $\mathrm{N} \mathrm{e}$ de $\mathrm{K}$, possibilitando uma maior economia de fertilizantes na solução nutritiva. 


\section{REFERÊNCIAS BIBLIOGRÁFICAS}

ARAÚJO, A.C.P.; MIDIO, A.F. Nitratos, nitritos e compostos N-nitrosos em alimentos: onde está o problema? Ciência e Cultura, v.40, p.947-956, 1989.

BARROS, I.B.I. Efeito de adubação nitrogenada, foliar e no solo, e da aplicação de molibdênio em alface (Lactuca sativa L.). Viçosa, 1979. 43p. Dissertação (M.S.) - Universidade Federal de Viçosa.

BEHR, U.; WIEBE, H.J. Relation between photosyntesis and nitrate content of lettuce cultivars. Scientia Horticulturae, v.49, p.175$179,1992$.

BLOM-ZANDSTRA, M.; LAMPE, J.E.M. The role of nitrate in the osmoregulation of lettuce (Lactuca sativa L.) grown at different light intensities. Journal of Experimental Botany, v.36, n.168, p.1043$1052,1985$.

BOON, J. van der; STEENNHUIZEN, J.W.; STEINGRÖVER, E.G. Effect of $\mathrm{EC}$, and $\mathrm{Cl}$ and $\mathrm{NH}_{4}{ }^{+}$concentration of nutrient solutions on nitrate accumulation in lettuce. Acta Horticulturae, n.222, p.3542, 1988. 
BOON, J. van der; STEENNHUIZEN, J.W.; STEINGRÖVER, E.G. Growth and nitrate concentration of lettuce as affected by nitrogen and chloride concentration, $\mathrm{NH}_{4}{ }^{+} / \mathrm{NO}_{3}{ }^{-}$ratio and temperature of the recirculating nutrient solution. The Journal of Horticultural Science, v.65, n.3, p.309-321, 1990.

BRAGA, R.M.; ABBOUD, A.C.S. Teores de nitrato em hortaliças provenientes de dois sistemas agrícolas de produção, orgânico e convencional, no Rio de Janeiro (Compact Disc). In: CONGRESSO BRASILEIRO DE CIÊNCIAS DO SOLO, 26., Rio de Janeiro, 1997. Anais. Rio de Janeiro: SBCS, 1997.

CAMPBELL, W.H. Nitrate reductase and its role in nitrate assimilation in plants. Physiologia Plantarum, v.74, n.2, p.214-219. 1988.

CATALDO, D.A.; HAROON, M.A.; SCHRADER, L.E.; YOUNGS, V.L. Rapid colorimetric determination of nitrate in plant tissue by nitration of salicilic acid. Communications in Soil Science and Plant Analysis, v.6, n.1, p.71-80, 1975.

CONTI, J. H. Caracterização de cultivares de alface (Lactuca sativa L.) adaptadas aos cultivos de inverno e verão. Piracicaba, 1994. 107 p. Dissertação ( M.S.) Escola Superior de Agricultura "Luiz de Queiroz", Universidade de São Paulo.

COSTA, A.S.V.; SILVA, N.F.; MARTINEZ, H.E.P.; FONTES, P.C.R.; PEREIRA, P.R.G. Utilização de fontes comerciais de fertilizantes no cultivo hidropônico de alface. Revista Ceres, v.44, p.169-179, 1997.

CROLL, B.T.; HAYES, C.R. Nitrate and wastes supplies in the United Kingdom. Environmental Pollution, v.50, p.163-187, 1988. 
DOUGLAS, J.S. Advanced guide to hydroponics: Soilless cultivation. 5.ed. London: Pelham Books, 1985. 368p.

FAQUIN, V.; FURTINI NETO, A.E.; VILELA, L.A.A. Produção de alface em hidroponia. Lavras: UFLA, 1996. 50p.

FAQUIN, V.; MARQUES, E.S.; SANTOS, H.S. Crescimento e concentração de nitrato em alface sob influência da relação $\mathrm{NO}_{3}$ : $\mathrm{NH}_{4}{ }^{+}$e cloro na solução nutritiva e do horário de colheita. In: REUNIÃO BRASILEIRA DE FERTILIDADE DO SOLO E NUTRIÇÃO DE PLANTAS, 21., Petrolina, 1994. Anais. Petrolina: SBCS, 1994. p.152-153.

FURLANI, P.R. Instruções para o cultivo de hortaliças de folhas pela técnica de hidroponia - NFT. Campinas: Instituto Agronômico, 1997. 30p. (IAC. Boletim Técnico 168).

GUPTA, V.C.; LIPSET, J. Molybdenum in soil, plants and animals Advances in Agronomy. v.34, p.73-109, 1981.

HOPKINS, W.G. Introduction to plant physiology. New York:John Wiley, 1995. 464p.

HUBER, S.C. Biochemical basis for effects of K-deficiency on assimilate export rate and accumulation of soluble sugars in soybean leaves. Plant Physiology, v.76, p.424-430, 1984.

JONES Jr., J.B. A guide for the hydroponic and soiless culture grower. Portland: Timber Press, 1983. 124 p. 
KANAAN, S.S.; ECONOMAKIS, C.D. Effect of climatic conditions and time of harvest on growth and nitrate content of lettuce in nutrient film culture. In: SYMPOSIUM ON SOIL AND SOILLESS MEDIA UNDER PROTECTED CULTIVATION IN MILD WINTER CLIMATES, Littlehampton, 1992. Acta Horticulturae, n.323, p.75-80, 1993.

KOEFENDER, V.N.; Crescimento e absorção de nutrientes pela alface cultivada em fluxo laminar de solução. Piracicaba, 1996, 85p. Dissertação (M.S.) - Escola Superior de Agricultura "Luiz de Queiroz", Universidade de São Paulo.

KOKSAL, G.; GURGAN, E.; KUCUKCEZZAR, R. Relationship of potassium deficiency and abscisic acid metabolism in soybean plants. Journal of Plant Nutrition, v.11, p.517-523, 1988.

LAVON, R. Effect of potassium, magnesium, and calcium deficiencies on carbohydrate pools and metabolism in Citrus leaves. Journal of the American Society for Horticultural Science, v.120, n.1, p.54$58,1995$.

LINDQVIST, K.B. On the origin of cultivated lettuce. Hereditas, v.46, p.387-470, 1960.

MALAVOLTA, E.; VITTI, G.C.; OLIVEIRA, S.A. Avaliação do estado nutricional das plantas. Piracicaba, POTAFOS, 1989. 210p.

MARSCHNER, H. Mineral nutrition of higher plants. 2.ed. London: Academic Press, 1995. 889 p.

MAYNARD, D.N.; BARKER, A.V. Nitrate content of vegetables crops. HortScience, v.7, n.3, p.224-226, 1972. 
MAYNARD, D.N.; BARKER, A. V.; MINOTTI, P.L.; PECK, N.H. Nitrate accumulation in vegetables. Advances in Agronomy, v.28, p.71$118,1976$.

MENGEL, K.; KIRKBY, E.A. Principles of plant nutrition. 4.ed. Bern: International Potash Institute, 1987. 687 p.

MICROSOFT CORPORATION. Microsoft excel para windows 95 v7.0. (software). New York, 1995.

OZBUN, J.L.; VOLK, R.J.; JACKSON, W.A. Effects of potassium deficiency on photosynthesis, respiration and utilization of photosynthesis reductant by mature bean leaves. Crop Science, v.8, p.427-430, 1965.

PACHECO, D.D. Índices de disponibilidade de nitrogênio, teores de nitrato e de vitamina $\mathrm{C}$, composição mineral e produção de repolho em resposta a doses de nitrogênio, de composto orgânico e de molibdênio. Viçosa, 1996. 79p. Dissertação (M.S.) - Universidade Federal de Viçosa.

PEOPLES, M.B.; FAIZAH, A.W.; RERKASEM, B.; HERRIDGE, D.F. Methodos for evaluating nitrogen fixation by nodulated legumes in the field. 1. ed. Canberra: ACIAR, 1989. 76p.

RAO, K.P.; RAINS, D.W. Nitrate absorption by barley. Plant Physiology, v.57, n.1. p.55-58, 1976.

REDINBAUGH, M.G.; CAMPBELL, W.H. Higher plant responses to environmental nitrate. Physiologia Plantarum, v.82, p.640-650, 1991. 
REININK, K. Genetics of nitrate accumulation in lettuce. Wageningen, 1993. 95p. Thesis (Ph.D.) - Agricultural University Wageningen.

REUTER, D.J.; ROBINSON, J.B. Plant analysis: an interpretation manual. 2.ed. Sydney: Inkata Press. 1997. 572p.

RICHARDSON, S.J.; HARDGRAVE, M. Effect of temperature, carbone dioxid enrichement, nitrogen form and rate of nitrogen fertiliser on the yield and nitrate content of two varieties of glasshouse lettuce. Journal of Science and Food Agriculture, v.59, p.345-349, 1992.

RISSE, L.A.; MCDONALD, R.E.; BARMORE, C.R. Packaging chopped lettuce in film bags. St. Joseph: ASAE, 1989. 10p. (Paper No. 896037).

RUFTY, T.W.; THOMAS, J.F.; REMMER, J.L.; CAMPBELL, W.H.; VOLK, R.J. Intercellular localization of nitrate reductase in roots. Plant Physiology, v.82, p.675-680, 1982.

SANTOS, H.S.; SOUZA, R.J. de Efeito de métodos de plantio e manejo do solo infestado com Meloidogyne javanica na produção de alface sob estufa plástica. Horticultura Brasileira, v.14, n.1, p.19-22, maio 1996.

SARRUGE, J.R. Soluções nutritivas. Summa Phytopatologica, v.1, p.231-233, 1975.

SARRUGE, J.R.; HAAG, H.P. Análises químicas em plantas. Piracicaba: ESALQ, 1974. 56 p.

SAS INSTITUTE. The SAS-system for windows: release 6.11 (software). Cary, 1996. 
SCHARPF, H.C. Nutrient influences on the nitrate content of vegetables. The Fertiliser Society, v.1, 1991. 224p. (Proceedings, 313).

SHIPPERS, P.A. Composition changes in the nutrition solution during the growth of plants in recirculating nutrient culture. In: SYMPOSIUM ON RESEARCH ON RECIRCULATING WATER CULTURE, Littlehampton, 1979. Acta Horticulturae, n.1, p.103118, 1980.

SRIVASTAVA, H.S. regulation of nitrate reductase activity in higher plants, Phytochemistry, v.19, n.5, p.725-733, 1980.

STEINGRÖVER, E.G.; STEENHUIZEN, J.W.; BOON, J. Van der. Effects of low intensities at night on nitrate accumulation in lettuce grown on a recirculation nutrient solution. Netherlands Journal of Agricultural Science, v.41, p.13-21, 1993.

\section{T.A.L. TECHNOLOGIES INCORPORATED. Software Wedge for windows} v1.2. (software). Philadelphia, 1997.

TERMINE, D.; LAIRON, D.; TAUPIER-LETAGE, B.; GAUTIER, S.; LAFOND,R.; LAFONT, H. Yield and content in nitrates, minerals and ascorbic acid of leeks and turnips grows under mineral or organic nitrogen fertilizations. Plant Foods for Human Nutrition, v.37, n.4, p.321-332, 1987.

WRIGHT, M.J.; DAVISON, K.L. Nitrate accumulation in crops and nitrate poisoning in animals. Advances in Agronomy, v.16, p.197241, 1964. 
ZITO, R.K.; FRONZA, V.; MARTINEZ, H.E.P.; PEREIRA, P.R.G.; FONTES, P.C.R. Fontes de nutrientes, relações nitrato:amônio e molibdênio, em alface (Lactuca sativa L.) produzida em meio hidropônico. Revista Ceres, v.41, p.419-430, 1994. 
ANEXOS 
Tabela A. 1. Valores de temperatura e umidade relativa do ar, tomadas na casa-de-vegetação durante o periodo experimental.

\begin{tabular}{|c|c|c|c|c|c|c|}
\hline \multirow[t]{2}{*}{ DATA } & \multicolumn{3}{|c|}{ Temperatura } & \multicolumn{3}{|c|}{ Umidade Relativa } \\
\hline & Máxima & Minima & Média & Máxima & Minima & Média \\
\hline $13 / 04 / 98(1)^{*}$ & 42 & 20 & 30,5 & 90 & 25 & 57,5 \\
\hline $14 / 04 / 98(2)$ & 42,5 & 19,5 & 30,5 & 91 & 20 & 55,5 \\
\hline $15 / 04 / 98(3)$ & 34 & 19,5 & 26,7 & 89 & 20 & 54,5 \\
\hline $16 / 04 / 98(4)$ & 43 & 20 & 31,5 & 88 & 25 & 55,7 \\
\hline $17 / 04 / 98(5)$ & 35 & 20 & 27,5 & 90 & 20 & 55 \\
\hline $18 / 04 / 98(6)$ & 32 & 19,5 & 25,7 & 90 & 20 & 55 \\
\hline $19 / 04 / 98(7)$ & 37 & 12 & 24,5 & 85 & 15 & 50 \\
\hline $20 / 04 / 98(8)$ & 35 & 14 & 24,5 & 85 & 20 & 52,5 \\
\hline $21 / 04 / 98$ (9) & 39 & 18 & 28,5 & 88 & 25 & 55,7 \\
\hline $22 / 04 / 98(10)$ & 40 & 16 & 28 & 88 & 20 & 54 \\
\hline $23 / 04 / 98(11)$ & 39 & 17 & 28 & 85 & 18 & 51,5 \\
\hline $24 / 04 / 98(12)$ & 37 & 19 & 28 & 85 & 35 & 60 \\
\hline 25/04/98 (13) & 38 & 17,5 & 27,7 & 88 & 30 & 59 \\
\hline $26 / 04 / 98(14)$ & 36 & 16 & 26 & 88 & 30 & 59 \\
\hline $27 / 04 / 98$ (15) & 34 & 19 & 26,5 & 85 & 30 & 57,5 \\
\hline $28 / 04 / 98(16)$ & 29 & 19 & 24 & 85 & 25 & 55 \\
\hline $29 / 04 / 98$ (17) & 38 & 18 & 28 & 90 & 65 & 77,5 \\
\hline
\end{tabular}

(*) Dias após o Transplante 
Tabela A. 2. Condições meteorológicas vigentes na estação meteorológica do Departamento de Física e Meteorologia da ESALQ/USP, durante o periodo experimental.

\begin{tabular}{cccccccc}
\hline DATA & $\begin{array}{c}\text { Radiação } \\
\text { Global } \\
\text { Cal cm }{ }^{-2} \mathrm{~d}\end{array}$ & $\begin{array}{c}\text { Insolação } \\
\mathrm{h} \mathrm{d}^{-1}\end{array}$ & $\begin{array}{c}\text { Precipitação } \\
\mathrm{mm}\end{array}$ & $\begin{array}{c}\mathrm{UR} \\
\%\end{array}$ & $\begin{array}{c}{ }^{0} \mathrm{C} \\
\text { Máxima } \\
\text { grau C }\end{array}$ & $\begin{array}{c}{ }^{\circ} \mathrm{C} \\
\text { Mínima } \\
\text { grau C }\end{array}$ & $\begin{array}{c}{ }^{0} \mathrm{C} \\
\text { Média } \\
\text { grau C }\end{array}$ \\
\hline $13 / 04 / 98(1)^{*}$ & 395 & 9,2 & 0,0 & 89 & 32,9 & 18,5 & 25,7 \\
$14 / 04 / 98(2)$ & 389 & 9,3 & 0,0 & 78 & 32,8 & 18,5 & 25,7 \\
$15 / 04 / 98(3)$ & 381 & 9,4 & 0,0 & 76 & 33,4 & 18,3 & 25,9 \\
$16 / 04 / 98(4)$ & 303 & 7,7 & 8,4 & 82 & 32,3 & 19,2 & 25,8 \\
$17 / 04 / 98(5)$ & 256 & 2,3 & 3,7 & 89 & 28,2 & 20,8 & 24,5 \\
$18 / 04 / 98(6)$ & 296 & 3,6 & 4,3 & 81 & 25,2 & 16,1 & 20,7 \\
$19 / 04 / 98(7)$ & 518 & 10,7 & 0,0 & 70 & 25,9 & 12,0 & 19,0 \\
$20 / 04 / 98(8)$ & 501 & 10,2 & 0,0 & 75 & 27,1 & 10,7 & 18,9 \\
$21 / 04 / 98(9)$ & 476 & 9,4 & 0,0 & 81 & 30,8 & 13,2 & 22,0 \\
$22 / 04 / 98(10)$ & 338 & 7,7 & 0,0 & 80 & 32,6 & 16,7 & 24,7 \\
$23 / 04 / 98(11)$ & 359 & 9,6 & 0,0 & 67 & 32,7 & 18,3 & 25,5 \\
$24 / 04 / 98(12)$ & 271 & 2,8 & 0,0 & 77 & 29,1 & 20,0 & 24,6 \\
$25 / 04 / 98(13)$ & 337 & 4,9 & 0,0 & 77 & 28,7 & 17,8 & 23,3 \\
$26 / 04 / 98(14)$ & 332 & 4,8 & 0,4 & 78 & 25,9 & 18,2 & 22,1 \\
$27 / 04 / 98(15)$ & 296 & 8,0 & 8,8 & 80 & 31,5 & 17,2 & 24,4 \\
$28 / 04 / 98(16)$ & 80 & 0,3 & 8,8 & 99 & 24,0 & 20,0 & 22,0 \\
$29 / 04 / 98(17)$ & 162 & 1,9 & 4,7 & 91 & 26,2 & 18,8 & 22,5 \\
\hline
\end{tabular}

(*) Dias após o Transplante 